Linköping Studies in Science and Technology

Dissertation No. 1625

\title{
Precursors and defect control for halogenated CVD of thick SiC epitaxial layers
}

\author{
Milan Yazdanfar
}

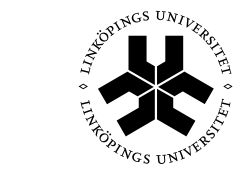

Linköping University INSTITUTE OF TECHNOLOGY

Semiconductor Material Division

Department of Physics, Chemistry and Biology (IFM)

Linköping University

SE-581 83 Linköping, Sweden

Linköping 2014 
(C) Milan Yazdanfar

ISSN: 0345-7524

ISBN: 978-91-7519-213-0

Printed by LiU-Tryck, Linköping, Sweden 2014 


\section{Contents}

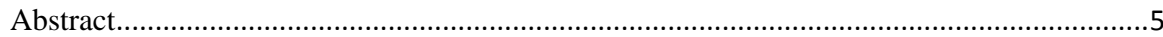

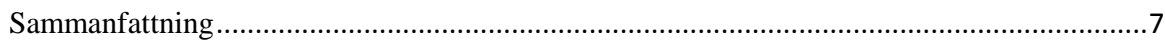

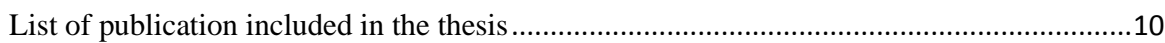

List of publication not included in the thesis......................................................................11

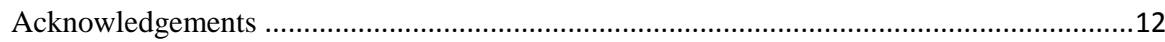

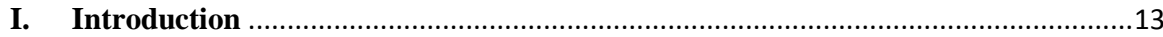

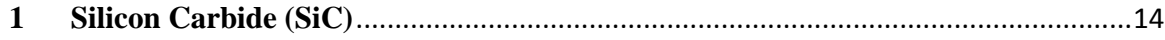

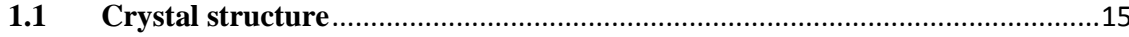

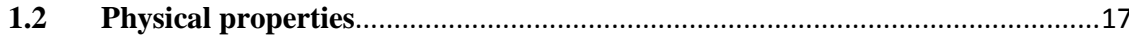

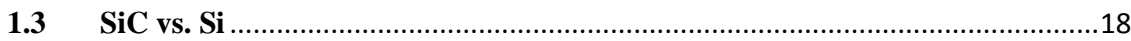

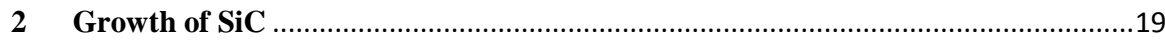

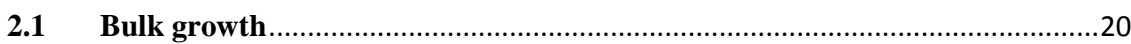

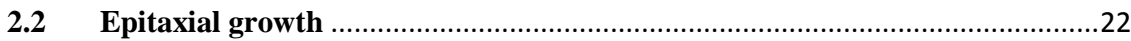

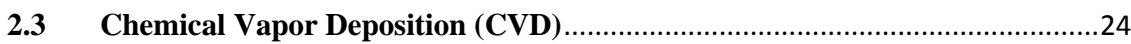

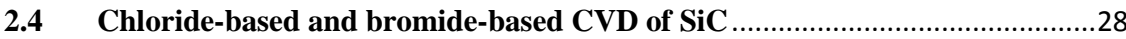

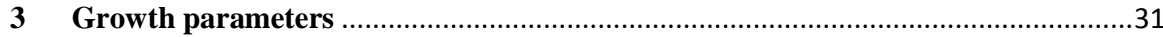

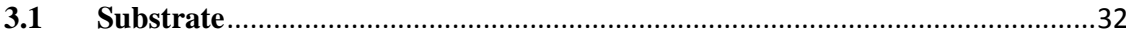

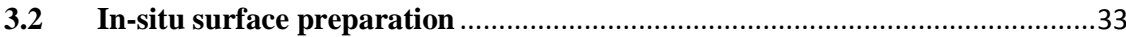

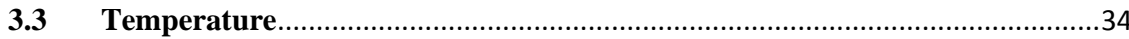

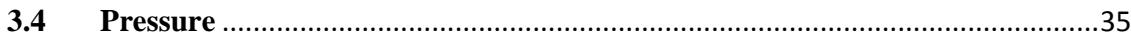

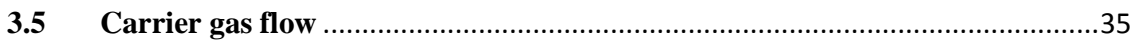

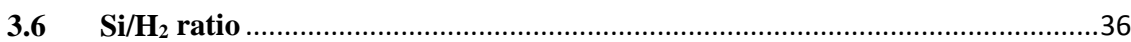

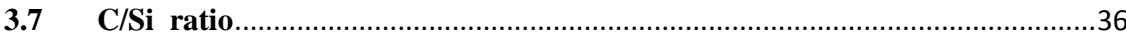

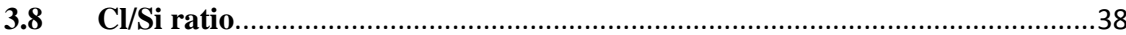

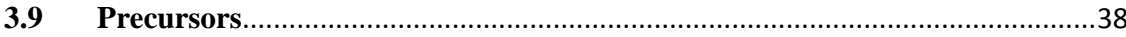

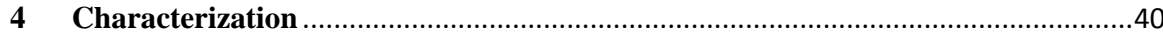

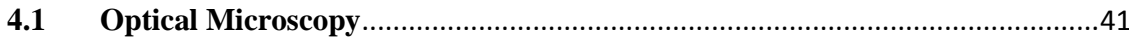

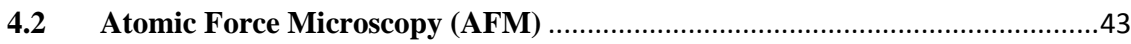

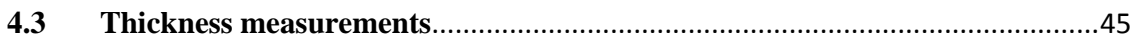

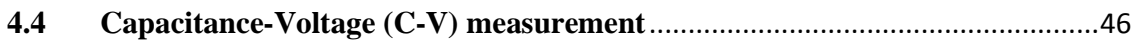

4.5 Low Temperature Photoluminescence (LTPL) ..........................................47 


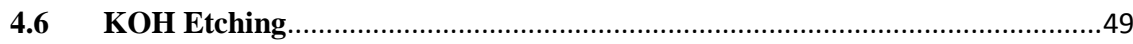

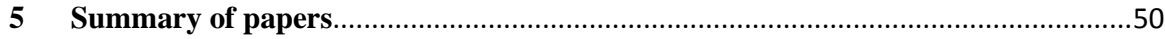

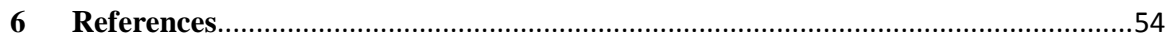

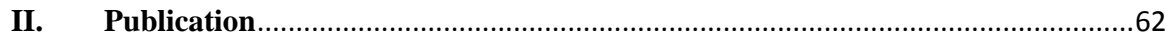

Paper 1-7 


\section{Abstract}

Silicon carbide $(\mathrm{SiC})$ is a very hard semiconductor material with wide band gap, high breakdown electric field strength, high thermal conductivity and high saturation electron drift velocity making it a promising material for high frequency and high power devices. The performance of electrical devices is strongly dependent on the quality, doping level and thickness of the grown epitaxial layers. The $\mathrm{SiC}$ epitaxial layers are usually grown by chemical vapor deposition (CVD), using silane $\left(\mathrm{SiH}_{4}\right)$ and light hydrocarbons $\left(\mathrm{C}_{2} \mathrm{H}_{4}\right.$ or $\left.\mathrm{C}_{3} \mathrm{H}_{8}\right)$ as precursors, diluted in a massive flow of hydrogen $\left(\mathrm{H}_{2}\right)$, at growth temperatures and pressures of $1500-1600{ }^{\circ} \mathrm{C}$ and 100-300 mbar, respectively. A Silicon Carbide $(\mathrm{SiC})$ device with a high breakdown voltage $(>10 \mathrm{kV})$ requires thick $(>100 \mu \mathrm{m})$ and low doped $\left(10^{14} \mathrm{~cm}^{-3}\right)$ epitaxial layers. The typical growth rate is usually $5-10 \mu \mathrm{m} / \mathrm{h}$, rendering very long growth times which result in a high cost for the final device. It is hard to increase the growth rate without running into problems with homogeneous gas phase nucleation, which badly affects the surface morphology and the usefulness of the epitaxial layers for devices. This problem can be avoided by lowering the growth pressure and/or increasing the carrier gas flow $\left(\mathrm{H}_{2}\right)$ to minimize the homogeneous gas phase nucleation or by increasing the growth temperature to evaporate the silicon droplets. On the other hand introducing chlorine into the gas mixture, by adding $\mathrm{HCl}$ or using some chlorinated silicon precursor, such as trichlorosilane $\left(\mathrm{SiHCl}_{3}\right)$ or tetrachlorosilane $\left(\mathrm{SiCl}_{4}\right)$, or by methyltrichlorosilane $\left(\mathrm{CH}_{3} \mathrm{SiCl}_{3}\right)$ as a single molecule will prevent nucleation in the gas phase. In this thesis a detailed study of the chloride-based processes and an investigation of a bromide-based CVD process is made using a horizontal hot wall reactor. Focus has been mainly on the study of various precursor molecules but also the effect of process parameters on the growth of thick epitaxial layers $(100-200 \mu \mathrm{m})$. In paper 1 the growth of SiC epitaxial layers on $4^{\circ}$ off-axis substrates manifesting very good morphology when using 
methane $\left(\mathrm{CH}_{4}\right)$ as carbon precursor is demonstrated. A comparative study of $\mathrm{SiCl}_{4}, \mathrm{SiHCl}_{3}, \mathrm{SiH}_{4}+\mathrm{HCl}, \mathrm{C}_{3} \mathrm{H}_{8}, \mathrm{C}_{2} \mathrm{H}_{4}$ and $\mathrm{CH}_{4}$ in an attempt to find the optimal precursor combination is presented in Paper 2 for growth of $4 \mathrm{H}-\mathrm{SiC}$ epitaxial layers on $4^{\circ}$ off-axis substrates with very good morphology. Paper 3 presents a direct comparison between chloride-based and bromide-based CVD chemistries for growth of $\mathrm{SiC}$ epitaxial layers using $\mathrm{SiH}_{4}$ and $\mathrm{C}_{2} \mathrm{H}_{4}$ as $\mathrm{Si}$ respectively $\mathrm{C}$-precursors with $\mathrm{HCl}$ or $\mathrm{HBr}$ as growth additives. The influence of temperature ramp up conditions on the carrot defect density on $8^{\circ}$ off-axis $4 \mathrm{H}-\mathrm{SiC}$ epitaxial layers using the single molecule precursor methyltrichlorosilane (MTS) as growth precursor is studied in Paper 4. In paper 5 growth of about $200 \mu \mathrm{m}$ thick epitaxial layers with very good morphology at growth rates exceeding $100 \mu \mathrm{m} / \mathrm{h}$ using $\mathrm{SiCl}_{4}+\mathrm{C}_{2} \mathrm{H}_{4}$ and $\mathrm{SiH}_{4}+\mathrm{HCl}+\mathrm{C}_{2} \mathrm{H}_{4}$ precursor approaches is reported. The effect of growth conditions on dislocation density by decorating the dislocations using $\mathrm{KOH}$ etching is reported in Paper 6. In Paper 7 the effect of varying parameters such as growth temperature, $\mathrm{C} / \mathrm{Si}$ ratio, $\mathrm{Cl} / \mathrm{Si}$ ratio, $\mathrm{Si} / \mathrm{H}_{2}$ ratio and in situ pregrowth surface etching time are studied in order to reduce the formation of step bunching and structural defects, mainly triangular defects for growth of about $100 \mu \mathrm{m}$ thick epitaxial layers on $4^{\circ}$ off-axis substrates with very good morphology at growth rates up to $115 \mu \mathrm{m} / \mathrm{h}$. 


\section{Sammanfattning}

Kiselkarbid ( $\mathrm{SiC}$ ) är ett hårt halvledarmaterial med stort bandgap, hög termisk konduktivitet, hög kritisk fältstyrka och hög elektron mobilitet. Det som framförallt gör SiC mycket bättre än kisel (Si) är den höga kritiska fältstyrkan som gör att SiC klarar höga spänningar och höga frekvenser, vilket är särskilt intressant för kraftkomponenter. Kärnan i en elektrisk komponent är det epitaxiella skiktet som har odlats ovanpå ett substrat. Elektriska komponenters prestanda beror på kvalitet, dopning och tjockleken av de odlade epitaxiella skikten. Den vanligaste tekniken för odling av epitaxiella skikt av SiC är Chemical Vapor Deposition (CVD). Silan ( $\left.\mathrm{SiH}_{4}\right)$ används som kiselkälla och lätta kolväten $\left(\mathrm{C}_{2} \mathrm{H}_{4}\right.$ eller $\left.\mathrm{C}_{3} \mathrm{H}_{8}\right)$ används som kolkällor, vilka i sin tur späds ut kraftigt i vätgas $\left(\mathrm{H}_{2}\right)$. Tillväxttemperaturen är ungefär $1500-1600{ }^{\circ} \mathrm{C}$ och tillväxttrycket är 100-300 mbar. En kiselkarbidkomponent med hög kritisk fältstyrka (> $10 \mathrm{kV}$ ) kräver tjocka (> $100 \mu \mathrm{m}$ ), lågdopade $\left(10^{14} \mathrm{~cm}^{-3}\right)$ epitaxiella skikt. Tillväxthastigheten för denna process är 5-10 mikrometer per timme, vilket gör tillverkningen av dessa komponenter mycket tidsödande och kostsam. Tillväxthastigheten kan ökas om man ökar silanflödet under tillväxt, men detta leder även till en ökning av formationen av kiseldroppar som bildas i gasfasen och när de kommer i kontakt med substratet så förstörs epilagret. Problemet med kiseldropparna kan lösas genom att lägga till något i gasblandningen som binder starkare till kisel än vad kisel binder till kisel, så att man kan öka koncentrationen av kisel i gasblandningen och därmed öka tillväxthastigheten betydligt. Normalt används klor som binder starkare till kisel, Si-Cl (bindningsenergi: $400 \mathrm{~kJ} / \mathrm{mol}$ ), än kisel till kisel, Si-Si (bindningsenergi: $224 \mathrm{~kJ} / \mathrm{mol}$ ) och därför kallas processen för klorid-baserad CVD. Bromid-baserad eller fluorid-baserad CVD kan också användas för ökning av tillväxthastigheten eftersom både brom och fluor binds starkare till kisel, Si-Br (bindningsenergi: 330 kJ/mol) och Si-F (bindningsenergi: 597 $\mathrm{kJ} / \mathrm{mol}$ ), än kisel till kisel. I denna avhandling presenteras utveklingen av 
klorid-baserade och bromid-baserade CVD processer för odling av epitaxiella skikt av 4H-SiC, främst genom att studera påverkan av olika prekursormolekyler. Påverkan av process-parametrar på tillväxten av tjocka epitaxiella skikt (100-200 $\mu \mathrm{m})$ av 4H-SiC har även studerats. Vi har använt metan $\left(\mathrm{CH}_{4}\right)$ som kolkälla för odling av epitaxiella skikt av 4H-SiC med mycket bra morfologi på $4^{\circ}$ off-axis substrater (Artikel 1). Vi har utfört en komparativ studie mellan $\mathrm{SiCl}_{4}, \mathrm{SiHCl}_{3}, \mathrm{SiH}_{4}+\mathrm{HCl}, \mathrm{C}_{3} \mathrm{H}_{8}, \mathrm{C}_{2} \mathrm{H}_{4}$ och $\mathrm{CH}_{4}$ för att hitta den optimala prekursor-kombinationen för odling av epitaxiella skikt av $4 \mathrm{H}-\mathrm{SiC}$ med bra morfologi (Artikel 2). Bromid-baserad CVD har används för första gången för odling av homoepitaxiella skikt av 4H-SiC med mycket bra morfologi och jämfördes med de klorid-baserade CVD proverna. För Bromidbaserad CVD använde vi $\mathrm{SiH}_{4}+\mathrm{C}_{2} \mathrm{H}_{4}+\mathrm{HBr}$ som prekursor-kombination och för klorid-baserad CVD användes $\mathrm{SiH}_{4}+\mathrm{C}_{2} \mathrm{H}_{4}+\mathrm{HCl}$ och det visade sig att Bromidbaserad CVD har ungefär $10 \%$ högre tillväxthastighet än för klorid-baserad CVD (Artikel 3). Metyltriklorsilan $\left(\mathrm{CH}_{3} \mathrm{SiCl}_{3}\right)$ användes för odling av $4 \mathrm{H}-\mathrm{SiC}$ epilager på $8^{\circ}$ off-axis substrat för att studera påverkan av olika in-situ etsningar av substratytan innan tillväxt på uppkomsten av morots-defekter. Det visade sig att $\mathrm{HCl}$ är mer effektiv än $\mathrm{C}_{2} \mathrm{H}_{4}$ för att förhindra bildning av morots-defekter (Artikel 4). Vi har använt $\mathrm{SiCl}_{4}+\mathrm{C}_{2} \mathrm{H}_{4}$ och $\mathrm{SiH}_{4}+\mathrm{HCl}+\mathrm{C}_{2} \mathrm{H}_{4}$ som prekursor-kombination för odling av $200 \mu \mathrm{m}$ tjocka 4H-SiC epilager på $8^{\circ}$ off-axis substrater med mycket bra morfologi med en tillväxthastighet på mer än 100 mikrometer per timme. Användning av lägre C/Si förhållande var nödvändigt för $\mathrm{SiCl}_{4}+\mathrm{C}_{2} \mathrm{H}_{4}$ processen för att kunna odla $200 \mu \mathrm{m}$ tjocka epilager med mycket bra morfologi (Artikel 5). Effekten av tillväxtparametrar på dislokationer studerades med $\mathrm{KOH}$ etsning för $100 \mu \mathrm{m}$ tjocka 4H-SiC epilager odlade på $4^{\circ}$ off-axis substrater (Artikel 6). Vi har minimerat uppkomsten av step-bunching och strukturella defekter i $100 \mu \mathrm{m}$ tjocka 4HSiC epilager på $4^{\circ}$ off-axis substrater genom att variera tillväxt-parametrar så som tillväxttemperatur, $\mathrm{C} / \mathrm{Si}$ förhållande, $\mathrm{Cl} / \mathrm{Si}$ förhållande, $\mathrm{Si} / \mathrm{H}_{2}$ förhållande och in-situ etsningar innan tillväxt. En tillväxthastighet på upp till 115 
mikrometer per timme och bra morfologi har uppnåtts efter denna optimering (Artikel 7). 


\section{List of publication included in the thesis}

1. On the use of Methane as Carbon Precursor in Chemical Vapor Deposition of Silicon Carbide

M.Yazdanfar, H. Pedersen, P. Sukkaew, I.G. Ivanov, Ö. Danielsson, O. Kordina, E. Janzén

Journal of Crystal Growth, 390 (2014) 24.

2. Finding the optimum chloride-based chemistry for chemical vapor deposition of $\mathrm{SiC}$

M.Yazdanfar , Ö. Danielsson, O. Kordina, E. Janzén, H. Pedersen

ECS Journal of Solid State Science and Technology, 3 (10) (2014) P320.

3. Bromine based chemistry for chemical vapor deposition of electronic grade $\mathrm{SiC}$

M.Yazdanfar, E. Kalered, Ö. Danielsson, O. Kordina, D. Nilsson, I. G. Ivanov, L. Ojamäe, E. Janzén, H. Pedersen

Submitted for publication

4. Carrot defect control in chloride-based CVD through optimized ramp up conditions

M. Yazdanfar, S. Leone, H. Pedersen, O. Kordina, A. Henry, E. Janzén Material Science Forum, 717-720 (2012) 109.

5. Process stability and morphology optimization of very thick 4H-SiC epitaxial layers grown by chloride-based CVD

M. Yazdanfar, P. Stenberg, I.D. Booker, I.G. Ivanov, O. Kordina, H.

Pedersen, E. Janzén

Journal of Crystal Growth, 380 (2013) 55-60.

6. Effect of process parameters on dislocation density in thick 4H-SiC epitaxial layers grown by chloride-based CVD on $4^{\circ}$ off-axis substrates

M. Yazdanfar, H. Pedersen, O. Kordina, E. Janzén

Material Science Forum, 778-780 (2014) 159 .

7. Reduction of structural defects in thick $4 \mathrm{H}-\mathrm{SiC}$ epitaxial layers grown on $4^{\circ}$ off-axis substrates

M. Yazdanfar, I.G. Ivanov, H. Pedersen, O. Kordina, E. Janzén

Journal of Applied Physics, 113 (2013) 223502. 


\section{List of publication not included in the thesis}

8. Morphology Optimization of Very Thick 4H-SiC Epitaxial Layers M. Yazdanfar, P. Stenberg, I.D. Booker, I.G. Ivanov, O. Kordina, H. Pedersen, E. Janzén Material Science Forum, 740-742 (2013) 251.

9. Simulation of gas-phase chemistry for selected carbon precursors in epitaxial growth of $\mathrm{SiC}$

Ö. Danielsson, P. Sukkaew, M.Yazdanfar, O. Kordina, E. Janzén Material Science Forum, 740-742 (2013) 213.

10. Thermal conductivity of isotopically enriched silicon carbide

B. Lundqvist, P. Raad, M. Yazdanfar, P. Stenberg, R. Liljedahl, P. Komarov, N. Rorsman, J. Ager, O. Kordina, I. Ivanov, E. Janzén

THERMINIC 2013 - 19Th International Workshop On Thermal Investigations Of Ics And Systems, Proceedings (2013) 58.

11. High-Resolution Raman and Luminescence Spectroscopy of Isotope- Pure ${ }^{28} \mathrm{Si}^{12} \mathrm{C}$, Natural and ${ }^{13} \mathrm{C}$ - Enriched $4 \mathrm{H}-\mathrm{SiC}$

I. G. Ivanov, M. Yazdanfar, B. Lundqvist, Jr-Tai Chen, J. Hassan, P. Stenberg, R. Liljedahl, N. T. Son, J. W. Ager III, O. Kordina, E. Janzén Material Science Forum, 778-780 (2014) 471. 


\section{Acknowledgements}

I would like to thank:

My supervisor Erik Janzén for giving me the chance to do the research on SiC, for encouraging, guiding and advising me. Thanks for believing in me.

My second supervisors Olle Kordina and Henrik Pedersen for helping and guiding me during my time at Linköping University. Thank you for sharing your great knowledge on SiC and CVD. Without you it would not be possible to write this thesis.

Ivan Ivanov for helping me with performing low temperature photoluminescence (LTPL) and for sharing your scientific knowledge.

Anne Henry and Stefano Leone for helping me in the lab with running the CVD reactor when I started my PhD studies.

Örjan Danielsson for your simulation studies and nice evenings during the conference in Japan.

Jawad ul Hassan for helping me with $\mathrm{KOH}$ etching and for useful discussions in the lab.

Reza Yazdi for helping me with Atomic Force Microscopy (AFM).

Sven Andersson and Roger Carmesten for support with technical problems in the lab.

Eva Wibom for your help in administrative issues.

Ian, Thang, Duc, Valdas, Martin, Daniel, Volodymyr, Pontus, Louise, Xun, Pitsiri, Björn, Ted, Chamseddine, Chao and the rest of the Semiconductor material group for having a nice environment and for all years we had together.

My family for their support and especially my brother Hiva for always being there for me.

My dearest wife Anna for your support, encouragement, and endless love. 
I. Introduction 
1 Silicon Carbide (SiC) 


\subsection{Crystal structure}

Silicon carbide (SiC) is a IV-IV compound semiconductor that consist of an equal number of silicon ( $\mathrm{Si}$ ) and carbon (C) atoms where each atom forms four bonds to four other atoms in a tetrahedral arrangement. The different stacking sequence of atomic bilayers ( $\mathrm{Si}$ and $\mathrm{C}$ atoms lying on the top of each other) leads to the formation of different polytypes [1]. There are (theoretically) more than 200 different SiC polytypes. The most studied SiC polytypes are 3C (ABC), $4 \mathrm{H}(\mathrm{ABCB})$ and $6 \mathrm{H}(\mathrm{ABCACB})$. 3C-SiC is usually called $\beta$-SiC and the others $\alpha$-SiC. In Figure 1 the stacking sequence of 3C-SiC, $4 \mathrm{H}-\mathrm{SiC}$ and $6 \mathrm{H}-\mathrm{SiC}$ is shown [2]. The open and closed circles indicate the silicon ( $\mathrm{Si}$ ) and carbon (C) atoms respectively. The occupation sites in the hexagonal closed packed structure are denoted by A, B and C. The $\mathrm{h}$ and $\mathrm{k}$ denote hexagonal and cubic sites respectively. The percentage of hexagonality of $6 \mathrm{H}-\mathrm{SiC}, 4 \mathrm{H}-\mathrm{SiC}$ and $3 \mathrm{C}-\mathrm{SiC}$ is 33,50 and $0 \%$ respectively $[3,4]$.

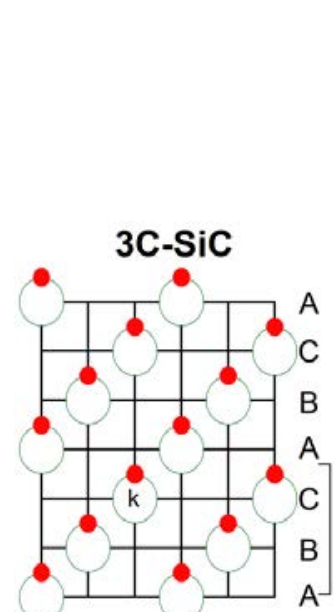

A $B$ C A B C

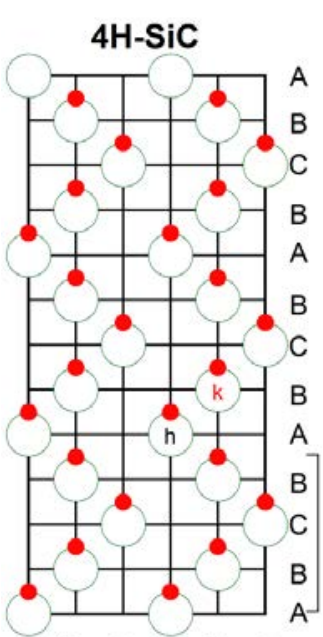

A B C A B C

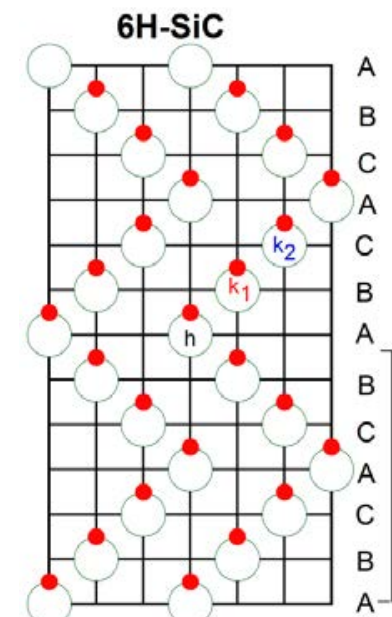

A $B$ C A A B C A

Figure 1: Arrangement of Si (open circles) and C (closed circles) atoms for different polytypes. The occupation sites in the hexagonal closed packed 
structure are denoted by A, B and C. The $\mathrm{h}$ and $\mathrm{k}$ indicate hexagonal and cubic sites respectively, from [2].

The SiC wafers have 2 orientations, Si-face and C-face which is a bulk property and not a surface property. On the Si-face and C-face, the $\mathrm{C}$ atoms and the Si-atoms are bonded to the Si-face surface and C-face surface with only one bond respectively. Figure 2 shows Si-face and C-face SiC that are also carbon and silicon terminated respectively.
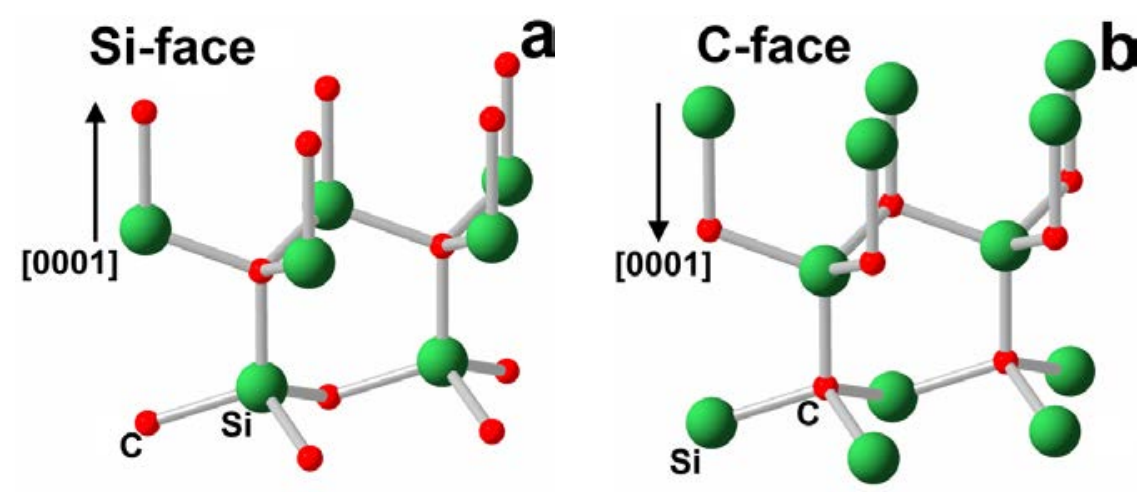

Figure 2: Arrangement of atoms in SiC for (a) Si-face (b) C-face. 


\subsection{Physical properties}

$\mathrm{SiC}$ is a very hard material with wide indirect band gap, high breakdown field, high thermal conductivity and high saturation electron drift velocity making it a promising material for high power and high frequency electronic devices. The high electric field breakdown strength of $\mathrm{SiC}$ which is about 10 times larger than that of Si and GaAs [5] is due to the wide band gap of SiC. The wide band gap leads also to a lower intrinsic charge carrier concentration $\left(\mathrm{n}_{\mathrm{i}}\right)$. High-energy phonons are obtained through the tight Si-C bonding [2]. The optical phonons in $\mathrm{SiC}$ have an energy in the 100-120 meV range [6], which leads to a high thermal conductivity [7] and high saturation electron drift velocity [8]. Table 1 shows some important physical properties of the most used semiconductors materials.

\begin{tabular}{|l|l|l|l|l|l|}
\hline $\begin{array}{l}\text { Semiconductor } \\
\text { Material }\end{array}$ & $\begin{array}{l}\mathrm{E}_{\mathrm{g}} \\
(\mathrm{eV})\end{array}$ & $\begin{array}{l}\mu \\
\left(\mathrm{cm}^{2} \mathrm{~V}^{-1} \mathrm{~s}^{-1}\right)\end{array}$ & $\begin{array}{l}\mathrm{E}_{\mathrm{B}} \\
\left(10^{6} \mathrm{~V} \mathrm{~cm}^{-1}\right)\end{array}$ & $\begin{array}{l}\lambda \\
\left(\mathrm{Wcm}^{-1} \mathrm{~K}^{-1}\right)\end{array}$ & $\begin{array}{l}\mathrm{V}_{\text {sat }} \\
\left(10^{7} \mathrm{~cm} \mathrm{~s}^{-1}\right)\end{array}$ \\
\hline 3C-SiC & 2.23 & 1000 & 1.2 & 4.9 & 2.7 \\
$4 \mathrm{H}-\mathrm{SiC}$ & 3.26 & 900 & 3 & 4.9 & 2 \\
$6 \mathrm{H}-\mathrm{SiC}$ & 3.02 & 450 & 2.1 & 4.9 & 2 \\
$\mathrm{Si}$ & 1.11 & 1350 & 0.3 & 1.5 & 1 \\
$\mathrm{GaAs}$ & 1.43 & 8000 & 0.4 & 0.45 & 2 \\
$\mathrm{GaN}$ & 3.40 & 1300 & 4 & 1.3 & 2.7 \\
AlN & 6.2 & 1100 & 11.7 & 2.5 & 1.5 \\
Diamond & 5.45 & 1900 & 10 & 20 & 2.7 \\
\hline
\end{tabular}

Table 1: Basic physical properties of some semiconductor materials [2, 9-13]. $E_{g}, \mu, E_{B}, \lambda$, and $V_{\text {sat }}$ are band gap, electron mobility, breakdown electric field, thermal conductivity and saturated electron drift velocity respectively 


\subsection{SiC vs. Si}

The breakdown electric field of $4 \mathrm{H}-\mathrm{SiC}$ is about ten times higher than for $\mathrm{Si}$ which make possible to design of SiC power diodes with 10 times thinner voltage blocking layers [13, 14]. In the case of bipolar devices where both electrons and holes are responsible for the current conduction, made of Si the switching speed is limited and switching losses are high due to the stored charge effects. The stored charge is the charge of the excess minority carriers at the depletion-layer edges and it must be removed before the device can be turned off. The use of $\mathrm{SiC}$ instead of $\mathrm{Si}$ improves the situation greatly because the epitaxial layers are thinner [15]. Due to the absence of the stored-charge effects in unipolar devices where only electrons are responsible for current conduction much faster switching and greatly reduced switching losses can be realized. However, the voltage ratings are limited and on-state resistance is high for Si unipolar devices. On the other hand the voltage ratings can be increased significantly while leakage current and on-state resistance are decreased when using $\mathrm{SiC}$ [16]. $\mathrm{SiC}$ has much lower intrinsic carrier concentration $\left(10^{-9} \mathrm{~cm}^{-3}\right)$ in contrast to $\mathrm{Si}\left(10^{10} \mathrm{~cm}^{-3}\right)$, resulting in a significantly greater capacity for high temperature operation [13]. 
2 Growth of SiC 


\subsection{Bulk growth}

In 1892 Edward G. Acheson developed a process to grow SiC polycrystals of different sizes at a temperature up to $2700{ }^{\circ} \mathrm{C}[17,18]$. The grown $\mathrm{SiC}$ could be used as an abrasive material or cutting tools. A process for the growth of $\mathrm{SiC}$ single crystals with higher crystalline quality was presented by Lely in 1955 [19]. In this method SiC single crystals were grown from the vapor phase by the sublimation technique at a temperature of $2550-2600{ }^{\circ} \mathrm{C}$. The main drawbacks of this method were: the high temperature of the process, small sizes of crystals, irregular shape of the crystals, and non-uniformities of doping and dislocation distribution in the grown material [20]. In 1978 Tairov and Tsvetkov developed a process that overcame those problems [21]. In this seeded sublimation method, also referred to as the modified Lely process, a seed crystal is used which makes it possible to grow of large sizes of $\mathrm{SiC}$ single polytype crystals. The growth temperature and the growth rate were in the $1800-2600{ }^{\circ} \mathrm{C}$ and $1-10 \mathrm{~mm} / \mathrm{h}$ ranges respectively. The driving force for this method is the axial temperature gradient of about $30^{\circ} \mathrm{C} / \mathrm{cm}$ with the seed temperature lower than the solid source temperature. In the beginning of the nineties the growth of single crystal $6 \mathrm{H}$ polytype $\mathrm{SiC}$ boules with a diameter up to $60 \mathrm{~mm}$ and low defect density had been reported [22, 23]. Nowadays high quality $\mathrm{SiC}$ single crystals wafer with a diameter up of to $150 \mathrm{~mm}$ are available on the market $[24,25]$. An alternative process to the seeded sublimation method is the high temperature chemical vapor deposition (HTCVD) process [26-29]. The growth is performed at a temperature of about 2000-2200 ${ }^{\circ} \mathrm{C}$ using gases of high purity such as silane $\left(\mathrm{SiH}_{4}\right)$ and ethylene $\left(\mathrm{C}_{2} \mathrm{H}_{4}\right)$ as silicon and carbon precursors respectively. Halide CVD (HCVD) is a growth technique which has a similar growth process to HTCVD that uses chlorinated precursors $\left(\mathrm{SiCl}_{4}\right)$ as silicon precursor and has been performed at a temperature of about $2000{ }^{\circ} \mathrm{C}$ [30, 31]. For silicon and carbon source a split gas injector is used and the gas exhaust is located at the bottom of the reaction chamber. A similar process has been performed at a temperature of $1850{ }^{\circ} \mathrm{C}$ 
[32]. The main differences from the HCVD are that the carbon and silicon sources entering collectively into the reaction chamber and the gas exhaust was located at the top of the reaction chamber. 


\subsection{Epitaxial growth}

The term epitaxy comes from the Greek words epi (above) and taxis (order) so epitaxial growth is the arranging of ordered growth on a substrate. The performance of electrical devices is strongly dependent on the quality, doping level and thickness of the grown epitaxial layers. There are two types of epitaxial growth; homoepitaxial growth when the substrate and the grown epitaxial layers are the same ( $\mathrm{SiC}$ epitaxial layers grown on $\mathrm{SiC}$ substrate), and heteroepitaxial growth when the substrate and the grown epitaxial layers are different ( $\mathrm{SiC}$ epitaxial layers grown on $\mathrm{Si}$ substrate). The main problem with heteroepitaxial growth is lattice mismatch between the grown epitaxial layers and the substrate which results in built in stress. Three types of growth modes can occur on the surface: a) 2D layer-by-layer (Frank-van der Merwe) takes place on the surface if the bonding between the adsorbed atoms and the substrate are stronger than they are to themselves; b) 3D island growth (Volmer-Weber) occurs when the adsorbed atoms are more strongly bonded to each other than to the substrate; c) is a combination of a) and b) i.e. layer-bylayer and island growth modes (Stranski-Krastanov). In the case of homoepitaxial growth of $\mathrm{SiC}$ the island growth mode occurs when an on-axis substrate is used. The on-axis substrates are the substrates that are sliced parallel to the basal plane (0001). The layer-by-layer growth is the required growth mode for $\mathrm{SiC}$ device application. This growth mode can be promoted by generating atomic steps on the surface, e.g. by slicing the $\mathrm{SiC}$ substrate with a slight off-angle to the c-axis (off-axis substrate). 
a

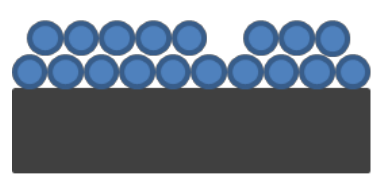

b

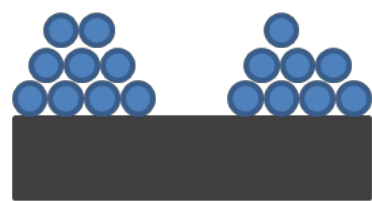

C

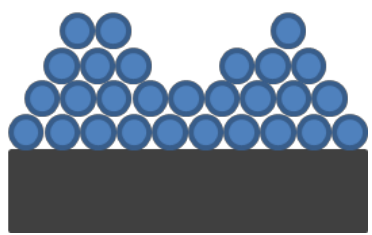

Figure 3: Basic growth modes, a) 2D layer-by-layer growth (Frank-van der Merwe); b) 3D island growth (Volmer-Weber); c) layer-by-layer plus island growth (Stranski-Krastanov). 


\subsection{Chemical Vapor Deposition (CVD)}

Chemical Vapor Deposition (CVD) involves the production of a film on a substrate by a chemical reaction of vapor-phase precursors in the gas phase and on the substrate. Heat (thermal CVD), higher frequency waves such as UV (photo-assisted CVD) or plasma (plasma-enhanced CVD) is used to initiate the chemical reaction of the precursors. For epitaxial growth of semiconductor material, the CVD process is the most established technique since the precursors used to produce the epitaxial layer are supplied as gases which can be provided with a very high level of purity. Moreover the doping level and thickness of the grown epitaxial layers, which are crucial for the performance of electrical devices, can easily be controlled in the CVD process. The basic physicochemical steps in an overall CVD reaction with a more detailed picture are shown in Figure 4 which indicates many key steps [33]:

1. Transport of the gas species (precursors) into the reaction zone (susceptor)

2. Gas phase reaction

3. Diffusion of the reacting species to the substrate surface

4. Adsorption of some species on the substrate surface

5. Surface diffusion of the adsorbed species to growth sites

6. Incorporation of species on the substrate surface

7. Mass transport of the non-adsorbed species and the desorbed species away from the reaction zone 


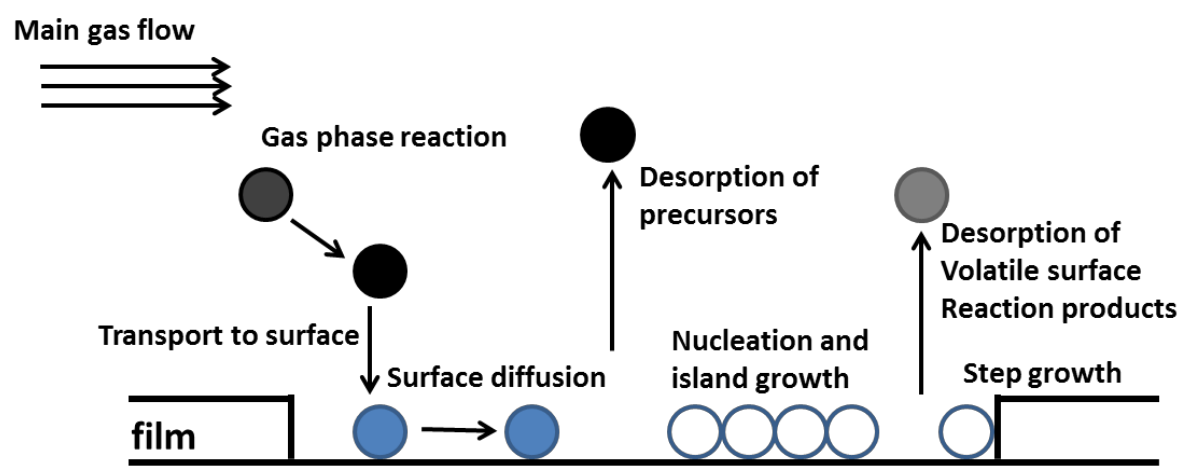

substrate

Figure 4: Reaction process and precursors transport in CVD, from [33]

The growth of epitaxial layers is determined by thermodynamics and kinetics. Thermodynamics provides a basic understanding of the growth system and allows the prediction of possible chemical reactions in the gas-phase when the system is in equilibrium. On the other hand, more detailed information such as the rate of the chemical reaction and which gas-phase reactions are actually important is given by kinetics. Figure 5 shows the dependence of epitaxial growth rate on the reciprocal growth temperature. There are three different growth regions:

1. The kinetic region, where the growth rate is dependent on the kinetics of gas-phase and/or surface reactions. The epitaxial layer growth rate increases when the growth temperature is increased.

2. The mass transport region, where the growth rate is independent of the growth temperature and determined by the diffusion of species through the boundary layer (the region in the gas phase close to the substrate surface) to the substrate surface. The mass transport growth region is the preferred region for most CVD processes. 
3. The thermodynamic region, where the epitaxial layer growth rate tends to decrease by increased growth temperature due to an increased rate of desorption and/or etching rate of the epitaxial layers.

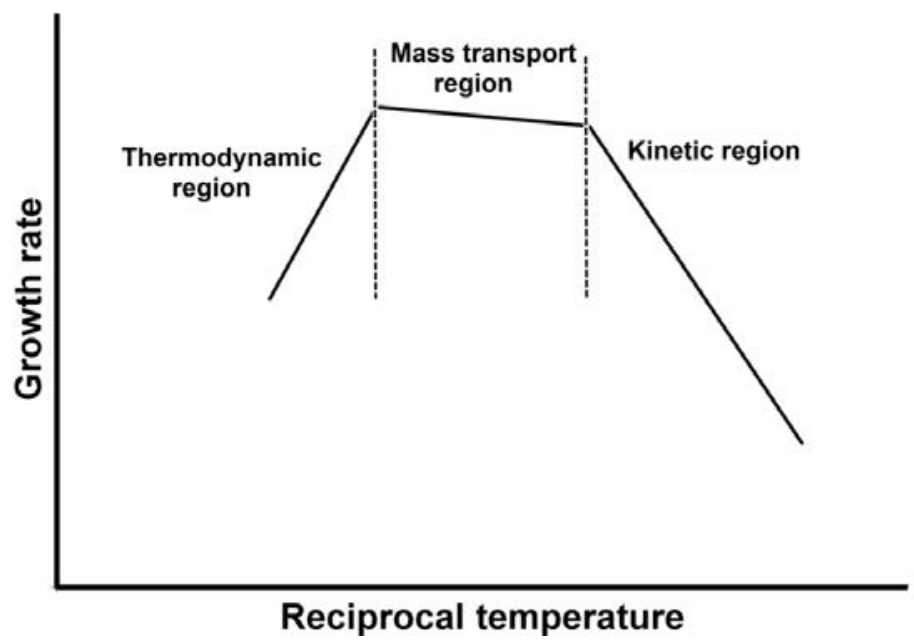

Figure 5: Different growth region dependence on growth temperature.

CVD reactors can have a horizontal configuration or a vertical configuration. The flow can be directed perpendicular o parallel to the substrate surface depending on the substrate position and gas flow (Figure 6). In hot-wall reactors the whole susceptor is heated while in cold wall reactors only the susceptor part where the substrate is placed is heated. Horizontal cold-wall CVD [34], vertical cold-wall CVD [35], vertical hot-wall CVD [36] and horizontal hot-wall CVD [37] have been used for epitaxial growth of SiC. In vertical reactors the substrates need to be mounted in some way, which could result in stress in the material due to thermal expansion, while in horizontal reactors the substrates are placed on the floor. The horizontal hot-wall CVD reactor is the most used reactor for the growth of $\mathrm{SiC}$ epitaxial layers due to a more uniform heat distribution and better cracking efficiency of the precursors which results in higher uniformity of growth rate and doping [38]. 


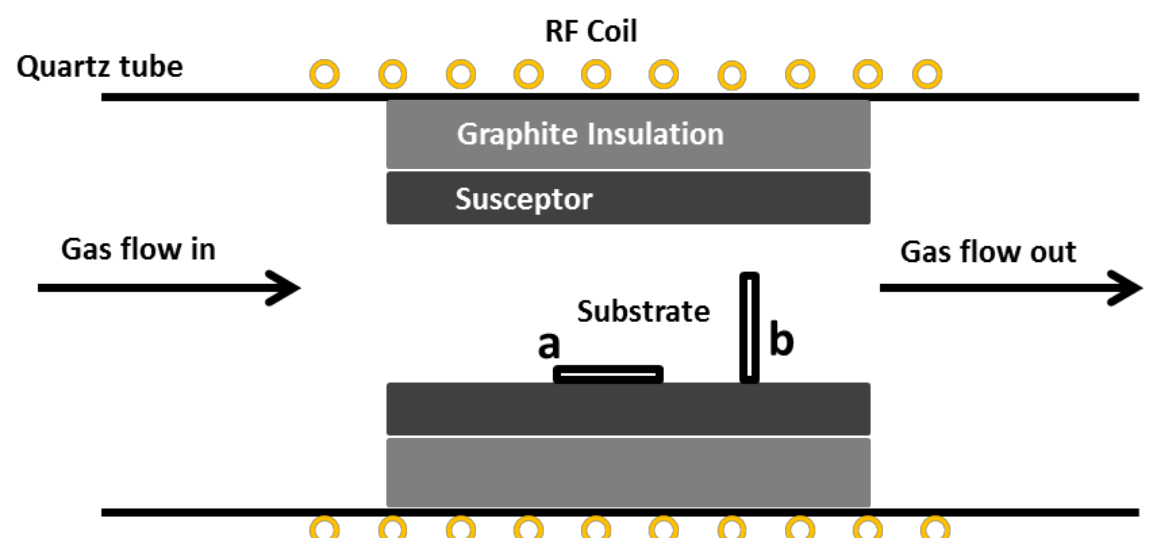

Figure 6: Schematic view of a horizontal hot-wall CVD reactor with different position of the substrates. The substrate surface $\mathbf{a}$ and substrate surface $\mathbf{b}$ are parallel and perpendicular to the gas flow respectively.

Metal-organic chemical vapor deposition (MOCVD) is a CVD process using metal-organic precursors which consist of a direct metal-carbon bond. The growth of III-nitride and III-V compounds are usually performed by MOCVD. The metal-organic precursors are usually toxic and pyrophoric when exposed to air and they are kept in bubblers.

In plasma-enhanced CVD (PECVD) electrical energy is used to form the chemically active species for deposition on the substrate surface. In PECVD, layer formation can take place at very low temperatures which makes this technique suitable for growth at low temperature and allows the use of temperature sensitive substrates. 


\subsection{Chloride-based and bromide-based CVD of SiC}

$\mathrm{SiC}$ epitaxial layers are traditionally grown by CVD, using silane $\left(\mathrm{SiH}_{4}\right)$ and light hydrocarbons $\left(\mathrm{C}_{2} \mathrm{H}_{4}\right.$ or $\left.\mathrm{C}_{3} \mathrm{H}_{8}\right)$ as precursors, diluted in a massive flow of hydrogen $\left(\mathrm{H}_{2}\right)$, at growth temperatures and pressures of $1500-1600{ }^{\circ} \mathrm{C}$ and 100-300 mbar, respectively. The typical growth rate when using this standard chemistry growth process is low (usually $5-10 \mu \mathrm{m} / \mathrm{h}$ ). It is hard to increase the growth rate without running into problems with homogeneous gas phase nucleation, which badly affects the surface morphology and the usefulness of the epitaxial layers for devices. A SiC device with a high breakdown voltage $(>10 \mathrm{kV})$ requires thick $(>100 \mu \mathrm{m})$ and low doped $\left(10^{14} \mathrm{~cm}^{-3}\right)$ epitaxial layers [39]. Thus, the growth of thick epitaxial layers with standard chemistry growth process requires a growth time of more than $10 \mathrm{~h}$, resulting in high cost for the final device. The formation of silicon droplets can be avoided by lowering the growth pressure and/or increasing the carrier gas flow $\left(\mathrm{H}_{2}\right)$ to minimize the homogeneous gas phase nucleation [40-42] or by increasing the growth temperature to evaporate the silicon droplets [43]. Low pressure vertical hot wall CVD (15-20 Torr) using standard chemistry $\left(\mathrm{SiH}_{4}+\mathrm{C}_{3} \mathrm{H}_{8}\right)$ has been reported to achieve high growth rates (> $100 \mu \mathrm{m} / \mathrm{h}$ ) [44, 45]. On the other hand introducing chlorine into the gas mixture (chloride-based) [46], by adding $\mathrm{HCl}$ [47-50] or using some chlorinated silicon precursor, such as trichlorosilane (TCS) [51-53] or tetrachlorosilane (TET) [54-56], or by using methyltrichlorosilane (MTS) [57-60] as a single molecule will prevent nucleation in the gas phase, due to the stronger Si-Cl bond $(400 \mathrm{~kJ} / \mathrm{mol})$ as compared to the Si-Si bond (226 kJ/mol) [61]. The addition of chlorine into the gas mixture alters the species involved in the reaction. The key point is the shift from $\mathrm{Si}$ to $\mathrm{SiCl}_{2}$ as the dominant $\mathrm{Si}$ providing species for the growth of $\mathrm{SiC}$ epitaxial layers $[62,63]$. It has been shown that $\mathrm{Si}$ is the main chemical species responsible for the formation of silicon droplets in the gas phase. On the other hand, $\mathrm{SiCl}_{2}$ is very stable and will contribute to the growth of $\mathrm{SiC}$ 
epitaxial layer, while at the same time preventing the formation of silicon droplets [62, 63].

Crippa et al. [47] and Myers et al. [48] reported for the first time the chloridebased CVD growth of $\mathrm{SiC}$ in a hot-wall CVD reactor at a growth temperature of about $1550{ }^{\circ} \mathrm{C}$ by introducing of $\mathrm{HCl}$ to the standard process $\left(\mathrm{SiH}_{4}+\mathrm{C}_{2} \mathrm{H}_{4}\right.$ or $\mathrm{C}_{3} \mathrm{H}_{8}$ ) resulting in a growth rate of $20 \mu \mathrm{m} / \mathrm{h}$ and $55 \mu \mathrm{m} / \mathrm{h}$ respectively. Higher growth rates $(>100 \mu \mathrm{m} / \mathrm{h})$ have also been achieved by adding $\mathrm{HCl}$ to the standard process $[49,50]$.

The use of trichlorosilane (TCS) as chlorinated silicon precursor has been reported for the first time by Leone et al. [52] and MacMillan et al. [53] in 2005 where $\mathrm{C}_{2} \mathrm{H}_{4}$ or $\mathrm{C}_{3} \mathrm{H}_{8}$ used as carbon precursor in a hot-wall CVD reactor at a growth rate of about $20 \mu \mathrm{m} / \mathrm{h}$. Higher growth rates $(>100 \mu \mathrm{m} / \mathrm{h})$ has also been reported using TCS and $\mathrm{C}_{2} \mathrm{H}_{4}$ [51].

The use of tetrachlorosilane (TET) together with propane $\left(\mathrm{C}_{3} \mathrm{H}_{8}\right)$ in the temperature range $1400-1850{ }^{\circ} \mathrm{C}$, in a hot-wall CVD reactor and at a growth rate up to $200 \mu \mathrm{m} / \mathrm{h}$ has been reported [54,55].

Methyltrichlorosilane (MTS or $\mathrm{CH}_{3} \mathrm{SiCl}_{3}$ ) as a single molecule has been used for chloride-based $\mathrm{SiC}$ growth since it has all the three chemical elements $(\mathrm{Si}$, $\mathrm{C}, \mathrm{Cl})$ required for the growth process. Bartlett et al. [59] and Zelenin et al. [60] reported for the first time chloride-based growth of SiC using MTS to growth 3C-SiC and 6H-SiC epitaxial layers respectively. The use of MTS has also been reported to obtain $4 \mathrm{H}-\mathrm{SiC}$ epitaxial layer with good quality and at growth rates higher than $100 \mu \mathrm{m} / \mathrm{h}[57,58]$.

Moreover chloromethane $\left(\mathrm{CH}_{3} \mathrm{Cl}\right)$ as chlorinated carbon precursor together with $\mathrm{SiCl}_{4}$ has been used for growth of $4 \mathrm{H}-\mathrm{SiC}$ epitaxial layers at low temperature $\left(1300-1400{ }^{\circ} \mathrm{C}\right)$ at a growth rate about $5 \mu \mathrm{m} / \mathrm{h}[64,65]$ and at higher temperature $\left(1600^{\circ} \mathrm{C}\right)$ at higher growth rate $(100 \mu \mathrm{m} / \mathrm{h})$ [56]. 
Furthermore fluoride-based and bromide-based chemistry could also be expected to work, i.e. preventing the formation of silicon droplets, due to the stronger Si-F (597 kJ/mol) and Si-Br (330 kJ/mol) bond strengths as compared to the Si-Si bond $(226 \mathrm{~kJ} / \mathrm{mol})$. Recently, interesting studies of fluoride-based chemistry have been reported to give good results [66], but no recent studies of bromine-based chemistry can be found. When looking for Br-based chemistry for $\mathrm{SiC} \mathrm{CVD} \mathrm{in} \mathrm{the} \mathrm{literature,} \mathrm{two} \mathrm{papers} \mathrm{comparing} \mathrm{methyl}$ trichlorosilane, $\mathrm{CH}_{3} \mathrm{SiCl}_{3}$ (MTCS) and methyl tribromosilane, $\mathrm{CH}_{3} \mathrm{SiBr}_{3}$ (MTBS) from 1995 can be found [67, 68]. We have reported a direct comparison between chloride-based and bromide-based CVD chemistries for $\mathrm{SiC}$ when $\mathrm{SiH}_{4}$ and $\mathrm{C}_{2} \mathrm{H}_{4}$ were used as $\mathrm{Si}$ - and C-precursors, respectively with $\mathrm{HCl}$ or $\mathrm{HBr}$ as growth additives [69]. We found that Br-based chemistry is as robust as Cl-based chemistry and that the growth rate is on average $10 \%$ higher for bromide-based chemistry compared to chloride-based chemistry which could be an indication of lower activation energy for the growth. 
3 Growth parameters 


\subsection{Substrate}

For homoepitaxial growth of $4 \mathrm{H}-\mathrm{SiC}$, wafers are usually cut with an $8^{\circ}$ or $4^{\circ}$ off-axis cut towards the [11-20] direction rendering a surface with atomic steps to facilitate step-flow controlled epitaxial growth [70] which makes it possible to achieve homopolytypic growth at lower temperature. The epitaxial layers grown on $4 \mathrm{H}-\mathrm{SiC}$ substrate with an off-cut of $8^{\circ}$ yields less surface defects. However, a large off-angle decreases the number of wafers that can be sliced from a single crystal boule, leading to a substantial amount of wasted material (up to 50\%), especially for 4" and 6" wafers. The use of lower off-cut angle reduces the material loss, thereby decreasing the total cost for the final device. In addition to that, the use of $4^{\circ}$ off-angle substrates leads to reduction of basal plane dislocations (BPD) in the epitaxial layers in contrast to the $8^{\circ}$ off-angle substrates [71, 72]. The presence and propagation of BPDs in the epitaxial layers are known to cause a drift of the forward voltage in bipolar devices during operation $[73,74]$. The main concerns in using $4^{\circ}$ off-angle substrates are usually the formation of step bunching (Figure 7) [75, 76] or triangular defects of different shapes and widths [77] on the epitaxial layers (Figure 8). The size of the triangular defects depend on the epitaxial layer thickness as these nucleate almost exclusively at the substrate epi interface. Conversely, the epitaxial layer thickness can be determined by measuring the length of the triangular defects:

\section{epitaxial layer thickness $=\tan \left(4^{\circ}\right) \times$ triangular defect length}

Here, the angle of $4^{\circ}$ is the off-cut angle of the substrates. The step bunching negatively influences the device performance [78] and it has been reported that the use of a low $\mathrm{C} / \mathrm{Si}$ ratio during growth [71] as well as epitaxial growth on the C-face of the substrate [77] reduces the step bunching. Furthermore, it has been proposed that the density of the triangular defects could be decreased using a low $\mathrm{C} / \mathrm{Si}$ ratio [79] or a higher $\mathrm{Cl} / \mathrm{Si}$ ratio [80] during the growth. Despite this the epitaxial layers are usually grown on the Si-face substrate due to the advantage of doping control [81]. 


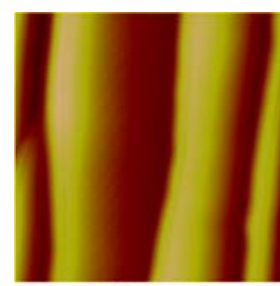

$\mathrm{C} / \mathrm{Si}=0.7$

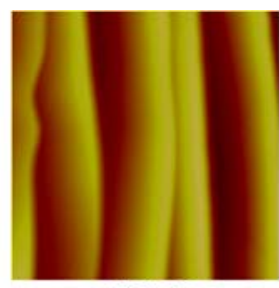

$\mathrm{C} / \mathrm{Si}=0.6$

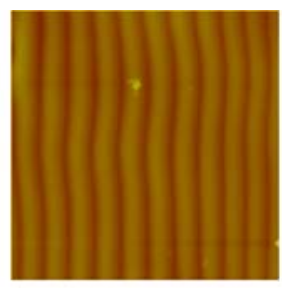

$\mathrm{C} / \mathrm{Si}=0.5$

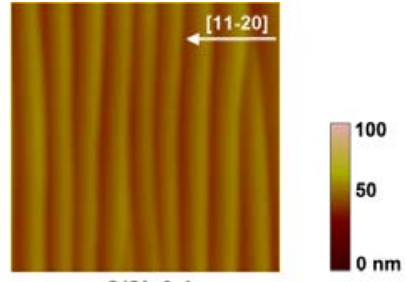

$\mathrm{C} / \mathrm{Si}=0.4$

Figure 7: AFM images of a $4 \times 4 \mu^{2}$ area of epitaxial layers with growth temperature $=1575^{\circ} \mathrm{C}, \mathrm{Cl} / \mathrm{Si}=5$, growth time $=63 \mathrm{~min}$ and $\mathrm{Si} / \mathrm{H}_{2}=0.25 \%$, and various $\mathrm{C} / \mathrm{Si}$ ratios.

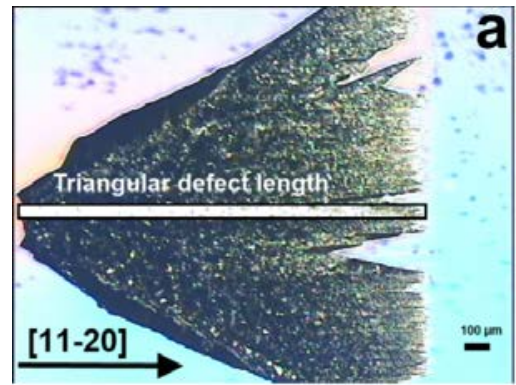

$\mathrm{C} / \mathrm{Si}=0.4-0.8$

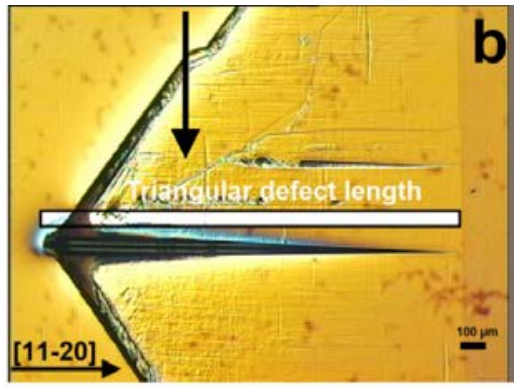

$\mathrm{C} / \mathrm{Si}=0.9-1.1$

Figure 8: Optical microscope images at 50 times magnification of triangular defects having different structure depending on the C/Si ratio.

\subsection{In-situ surface preparation}

The proper surface preparation prior to epitaxial growth will decrease the density of surface defects on the substrates which is very important for growing epitaxial layers of good quality [82]. Silicon species evaporate faster than carbon species in vacuum, but in hydrogen ambient carbon atoms on the surface react with the hydrogen to form hydrocarbons, allowing carbon to be desorbed fast from the surface [83]. Similar reactions between hydrogen and silicon atoms are slower leading to a faster removal of carbon than silicon 
from the surface, when etching is done in pure hydrogen ambient. Addition of $\mathrm{HCl}$ will increase desorption of silicon from the surface through reactions between $\mathrm{Si}$ and $\mathrm{Cl}$ and possibly also $\mathrm{H}$ atoms forming of $\mathrm{SiH}_{\mathrm{x}} \mathrm{Cl}_{\mathrm{y}}$ species. Etching of carbon by chlorine is not likely given the lower bond enthalpy for C-Cl $324 \mathrm{kJmol}^{-1}$ compared to C-H $414 \mathrm{kJmol}^{-1}$ while the bond enthalpies for Si-Cl and Si-H are 400 respectively $323 \mathrm{kJmol}^{-1}$ [84], indicating that Si will mainly be etched by $\mathrm{Cl}$. Thus the addition of $\mathrm{HCl}$ will lead to an etching process that removes $\mathrm{Si}$ and $\mathrm{C}$ at similar rates which enables a smoother $\mathrm{SiC}$ surface with less surface defects [85]. On the other hand an addition of $\mathrm{C}_{2} \mathrm{H}_{4}$ will suppress evaporation of carbon from the surface [86]. $\mathrm{SiH}_{4}$ has been used as etching agent for on-axis substrates [87]. It should be noted that the in-situ surface preparation is also dependent on other factors, such as the substrate polarity, surface quality, the reactor geometry, the etching temperature and time.

\subsection{Temperature}

The growth temperature for epitaxial growth of $4 \mathrm{H}-\mathrm{SiC}$ is usually in the 1500 $1600{ }^{\circ} \mathrm{C}$ range where the growth rate is independent of the growth temperature and determined by the mass transport. When using $4^{\circ}$ off-angle substrates the formation of step bunching or triangular defects can be controlled by the growth temperature [79, 88]. At higher temperature the formation of step bunching is increased while the density of the triangular defects is decreased. The growth of $4 \mathrm{H}-\mathrm{SiC}$ epitaxial layers grown on $8^{\circ}$ off-axis substrates has been reported at low temperature $\left(1300{ }^{\circ} \mathrm{C}\right)[65,89]$ where the growth is dependent on the gas-phase and/or surface reactions and the growth rate increases when the growth temperature is increased. At a temperature of 1300 ${ }^{\circ} \mathrm{C}$ the growth rate was about $12 \mu \mathrm{m} / \mathrm{h}$ and a high $\mathrm{Cl} / \mathrm{Si}$ ratio of 6 was required to avoid the formation of silicon droplets while at the temperature of $1500{ }^{\circ} \mathrm{C}$ using a $\mathrm{Cl} / \mathrm{Si}$ ratio of 3 the growth rate increased to $18 \mu \mathrm{m} / \mathrm{h}$ and no silicon droplets were observed [89]. It has been reported that the nitrogen 
incorporation increases when increasing the growth temperature (1500-1600 ${ }^{\circ} \mathrm{C}$ ) for epitaxial layers grown on Si-face [90-93] and decreases for C-face [90, 92, 93].

\subsection{Pressure}

The gas speed in the reactor is inversely proportional to the pressure while the boundary layer thickness is proportional to it [94]. At low pressure (100-200 mbar) the species reach the substrate surface more easily due to a decrease in boundary layer thickness. At high pressure it is hard to keep good gas flow uniformity in the susceptor. The gas phase reactions increase by increasing the pressure resulting in a higher growth rate but at the same time the morphology of the grown epitaxial layers degrades. Figure 9 shows the epitaxial layers grown at 200 and 400 mbar having a growth rate of 120 and $180 \mu \mathrm{m} / \mathrm{h}$, respectively.
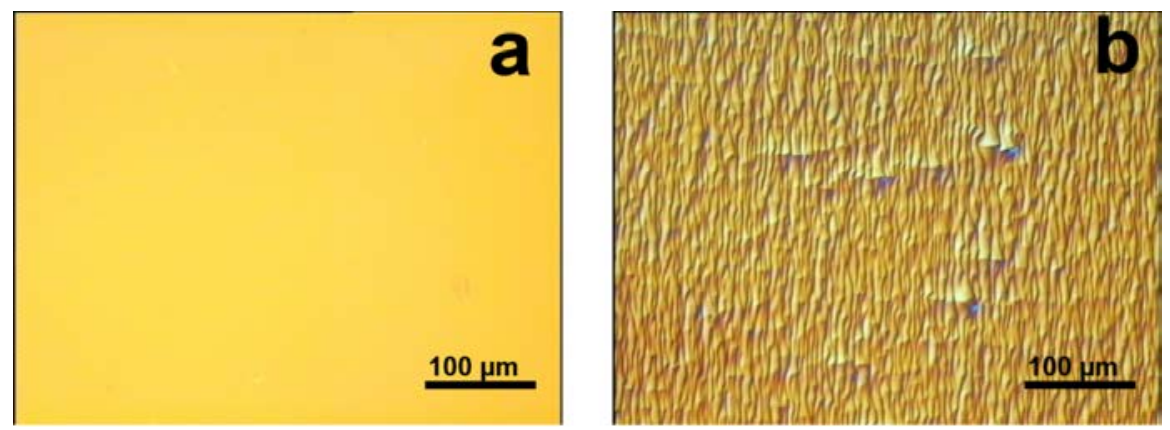

Figure 9: Optical microscope images at 200 times magnification of thick 4H$\mathrm{SiC}$ epitaxial layers with $\mathrm{C} / \mathrm{Si}=0.8, \mathrm{Cl} / \mathrm{Si}=4$, growth time $=1$ hour and $\mathrm{Si} / \mathrm{H}_{2}=0.25 \%$, with (a) pressure of $200 \mathrm{mbar}$ and growth rate of $120 \mu \mathrm{m} / \mathrm{h}$; (b) pressure of 400 mbar and growth rate of $180 \mu \mathrm{m} / \mathrm{h}$.

\subsection{Carrier gas flow}

Palladium membrane purified hydrogen $\left(\mathrm{H}_{2}\right)$ is usually used as carrier gas in CVD process for SiC. Hydrogen carries the precursors into the reaction chamber and also participates in the gas phase reaction together with the 
precursors to obtain the species for crystal growth [95]. It has been reported that a high flow of $\mathrm{H}_{2}$ prevents the formation of silicon droplets [42]. Moreover $\mathrm{H}_{2}$ is acting as etching agent especially to removed carbon and/or carbon species from the substrate surface.

\section{$3.6 \mathrm{Si} / \mathrm{H}_{2}$ ratio}

The $\mathrm{Si} / \mathrm{H}_{2}$ ratio indicates the amount of precursors that are used for growth of epitaxial layers. The growth rate is usually increased linearly when increasing the $\mathrm{Si} / \mathrm{H}_{2}$ ratio. The doping decreases as the growth rate increases since at higher growth rate the probability for incorporation of nitrogen atoms is smaller [88]. It should be noted that the dependence of background doping concentration on the $\mathrm{Si} / \mathrm{H}_{2}$ ratio is not linear (figure 10). The doping concentration drops from high $10^{13}$ to low $10^{13}$ by increasing $\mathrm{Si} / \mathrm{H}_{2}$ ratio from $0.15 \%$ to $0.25 \%$.

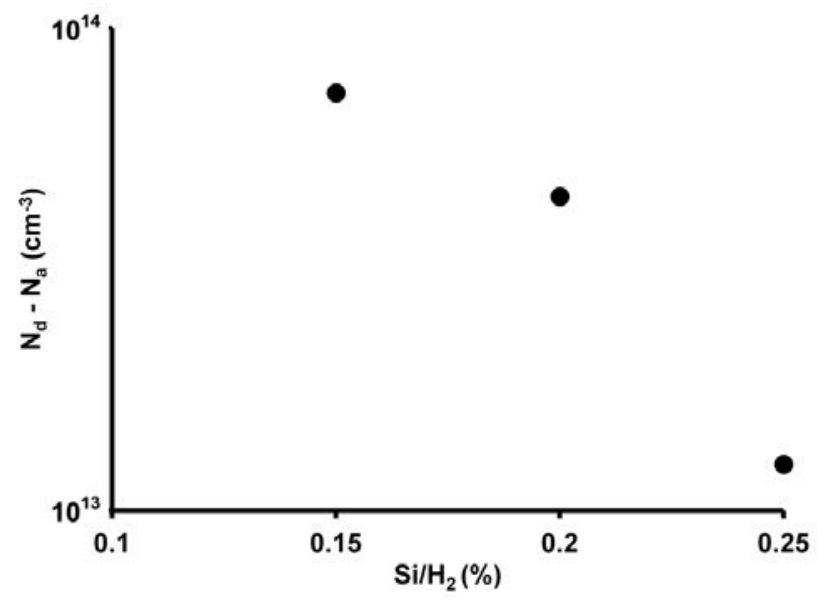

Figure 10: Background doping concentration of $4 \mathrm{H}-\mathrm{SiC}$ epitaxial layers grown on the Si-face substrates.

\section{$3.7 \quad \mathrm{C} / \mathrm{Si}$ ratio}

The $\mathrm{C} / \mathrm{Si}$ ratio is a very powerful growth parameter for growth of epitaxial SiC layers. The growth rate is usually constant above a critical C/Si ratio but drops 
below that critical C/Si ratio due to the lack of carbon [96]. In figure 11 the growth rate for various $\mathrm{C} / \mathrm{Si}$ ratios with constant silane flow is plotted. It can be seen that in the Si-limited growth region (high $\mathrm{C} / \mathrm{Si}$ ratio), the growth rate is constant and controlled by the Si supply while in the C- limited growth region (low $\mathrm{C} / \mathrm{Si}$ ratio) the growth rate decreases and controlled by $\mathrm{C}$ supply. The 3C-polytype is more stable at higher carbon partial pressure [97] and thus the formation of $3 \mathrm{C}$ of the growing epitaxial layers can be prevented at low $\mathrm{C} / \mathrm{Si}$ ratio. The triangular defects density decreases with decreasing $\mathrm{C} / \mathrm{Si}$ ratio $[79,88]$. The formation of step bunching has been reported at very low or high $\mathrm{C} / \mathrm{Si}$ ratio [98]. The step bunching is formed by occurrence of carbon or silicon clusters on the terraces due to excessive flow of carbon or silicon precursors. The doping concentration is dependent on the C/Si ratio according to the site-competition model [99]. The nitrogen incorporation is inversely proportional to the $\mathrm{C} / \mathrm{Si}$ ratio since the nitrogen atoms occupy carbon sites on the grown epitaxial layers. It should be noted that the site-competition model is not valid for the epitaxial growth using standard chemistry on C-face substrates $[100,101]$. It has been explained by the fact that $\mathrm{Si}$ atoms are bonded to the C-face surface with only one bond and due to the high growth temperature will evaporate resulting that the $\mathrm{C}$-face will be terminated with $\mathrm{C}$ atoms even at very low $\mathrm{C} / \mathrm{Si}$ ratio. On the other hand it has been shown that the site-competition model is valid for chloride-based SiC CVD on the C-face substrates [102]. 


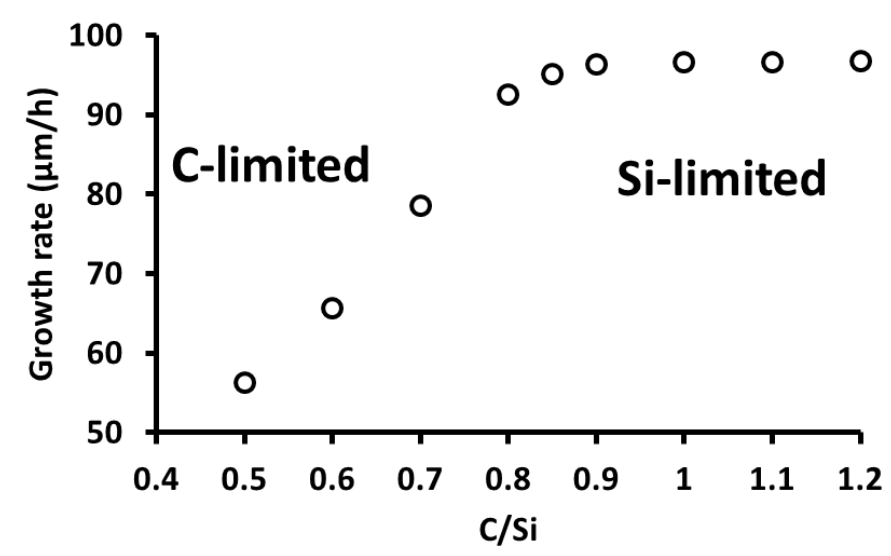

Figure 11: Growth rate of $4 \mathrm{H}-\mathrm{SiC}$ epitaxial layers for various $\mathrm{C} / \mathrm{Si}$ ratios with constant silane flow.

\section{$3.8 \mathrm{Cl} / \mathrm{Si}$ ratio}

As mentioned above, chlorine is introduced into the gas mixture (chloridebased epitaxial layers) to achieve a high growth rate and to prevent the formation of silicon droplets at the same time. It has been reported that the morphology of the grown epitaxial layers [49] and the growth rate [103, 57] are affected by $\mathrm{Cl} / \mathrm{Si}$ ratio. A decrease in growth rate for high $\mathrm{Cl} / \mathrm{Si}$ ratio [57] due to etching effects and for low $\mathrm{Cl} / \mathrm{Si}$ ratio [103] due to insufficient formation of $\mathrm{SiCl}_{2}$ has been reported.

\subsection{Precursors}

Commonly, propane $\left(\mathrm{C}_{3} \mathrm{H}_{8}\right)$ and ethylene $\left(\mathrm{C}_{2} \mathrm{H}_{4}\right)$ are used as carbon precursors for growth of $\mathrm{SiC}$ epitaxial layers. It is generally considered that the use of methane $\left(\mathrm{CH}_{4}\right)$ as carbon precursor is not suitable since a CVD process using $\mathrm{CH}_{4}$ renders epitaxial layers with high surface roughness and high density of surface defects [104]. We have demonstrated that it is possible to use $\mathrm{CH}_{4}$ as carbon precursor in CVD of high quality epitaxial layers of SiC, by carefully optimizing the $\mathrm{C} / \mathrm{Si}$ ratio to achieve a growth chemistry that is neither carbon 
nor silicon limited [105]. Also we have studied the use of silane $\left(\mathrm{SiH}_{4}\right)$, trichlorosilane $\left(\mathrm{SiHCl}_{3}\right)$ and tetrachlorosilane $\left(\mathrm{SiCl}_{4}\right)$ as silicon precursors, and propane $\left(\mathrm{C}_{3} \mathrm{H}_{8}\right)$, ethylene $\left(\mathrm{C}_{2} \mathrm{H}_{4}\right)$ and methane $\left(\mathrm{CH}_{4}\right)$ as carbon precursors [106]. It was found that the $\mathrm{SiHCl}_{3}$ - based process using $\mathrm{C}_{3} \mathrm{H}_{8}$ shows the highest growth efficiency while the $\mathrm{SiH}_{4}$ - based process using $\mathrm{CH}_{4}$ shows the lowest growth efficiency (Figure 12).

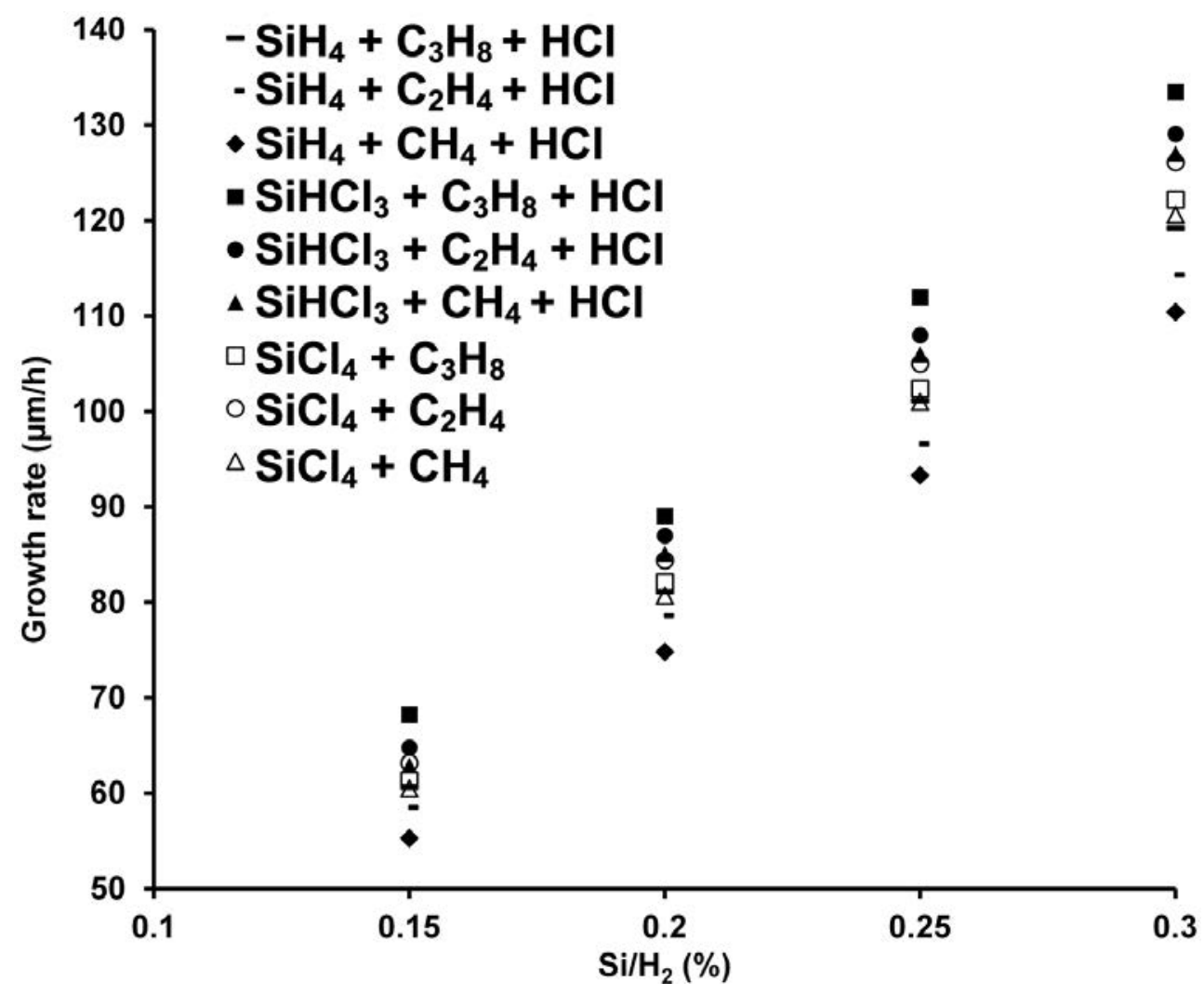

Figure 12: Dependence of growth rate on the $\mathrm{Si} / \mathrm{H}_{2}$ ratio with $\mathrm{C} / \mathrm{Si}=1$, $\mathrm{Cl} / \mathrm{Si}=4$ and growth time $=15 \mathrm{~min}$ for $4 \mathrm{H}-\mathrm{SiC}$ epitaxial layers using silane $\left(\mathrm{SiH}_{4}\right)$, trichlorosilane (TCS) and tetrachlorosilane (TET) as silicon precursor and propane $\left(\mathrm{C}_{3} \mathrm{H}_{8}\right)$, ethylene $\left(\mathrm{C}_{2} \mathrm{H}_{4}\right)$ and methane $\left(\mathrm{CH}_{4}\right)$ as carbon precursor. 
4 Characterization 


\subsection{Optical Microscopy}

Optical microscopy is a very fast and useful tool to study the morphology of the epitaxial layers. The quality of the grown epitaxial layers can be evaluated by surface morphology, defects density and overall uniformity. The thickness of grown epitaxial layers can be estimated by looking at cross sections of cut or cleaved samples or from the length of triangular defects or carrot defects. An optical microscope image of an epitaxial layer with bad morphology and a cross section view of a $190 \mu \mathrm{m}$ thick epitaxial layers is shown (Figure 13). In Figure 13b the doping level of the substrate is high $\left(>10^{18} \mathrm{~cm}^{-3}\right)$ while the doping level of the grown epitaxial layers is low $\left(10^{14}-10^{15} \mathrm{~cm}^{-3}\right)$ which makes it possible to see their interface.
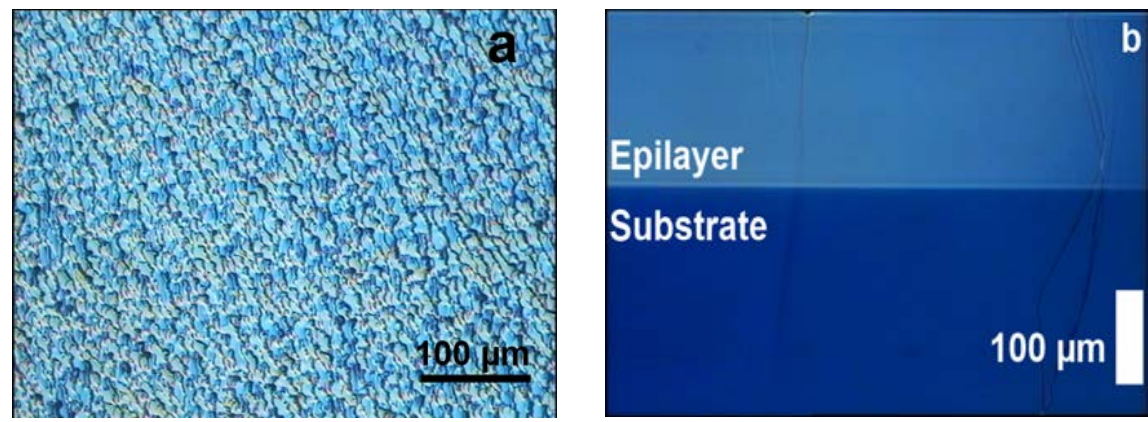

Figure 13: Optical microscope image at 200 times magnification of (a) 150 $\mu \mathrm{m}$ thick epitaxial layers with bad morphology; (b) cross section view of 190 $\mu \mathrm{m}$ thick epitaxial layers.

In Nomarski differential interference contrast (NDIC) microscopy, light from a lamp is polarized by passing it through a polarizer and then through a Nomarski prism that splits it into two beams going in slightly different direction but vibrating orthogonally to each other. The distance between the beams is called the shear and it is less than the resolution of the objective lens. The split beams then illuminate the sample and are reflected back. The difference in their paths caused by surface irregularities such as varying 
thickness and slopes will result in interference between the split beams which results in contrast. 


\subsection{Atomic Force Microscopy (AFM)}

Atomic force microscopy (AFM) is used to study the morphology of epitaxial layers on an atomic scale. AFM can be operated in three modes: contact mode, tapping mode and non-contact mode [107]. Contact mode AFM works by scanning a tip fixed to the end of a cantilever over the substrate surface while the change in cantilever deflection is monitored by a photodiode detector which records the reflection of a laser focused on the tip of the cantilever. A constant deflection between the cantilever and the substrate is kept by vertically moving the scanner at each (x,y) data point. The force between the tip and the substrate remains constant by keeping a constant cantilever deflection. The force is given by Hooke's law:

$\mathrm{F}=-\mathrm{kx}$

where $\mathrm{F}, \mathrm{k}$ and $\mathrm{x}$ are force, spring constant and cantilever deflection respectively. In tapping mode AFM the cantilever is oscillated at high frequency (200-400 kHz) and the tip taps on the substrate surface during scanning in contrast to contact mode where the cantilever is not oscillating and the tip is dragged on the substrate surface. By keeping constant oscillation amplitude (20 - $100 \mathrm{~nm}$ ), the interaction between the tip and the substrate surface is kept constant during scanning. In non-contact mode AFM the cantilever is oscillated but the tip does not contact the substrate surface but is kept at a constant height above the surface. The cantilever length and the tip radius are about $125 \mu \mathrm{m}$ and 5-10 nm respectively. An AFM system is schematically shown in figure 14 . 


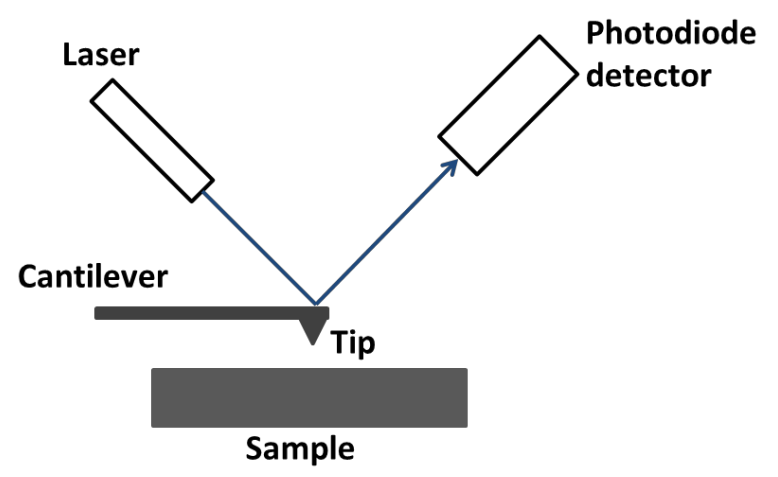

Figure 14: Schematic view of atomic force microscopy (AFM). 


\subsection{Thickness measurements}

As mentioned above the thickness of the grown epitaxial layers can be estimated by measuring the length of a triangular or carrot defect or by looking at the cross section view of cleaved substrates with an optical microscope. On the other hand Fourier transform infrared reflectance spectroscopy (FTIR) is a non-destructive, fast and more precise technique for the thickness measurement [108]. An interferometer (Michelson interferometer) is used to measure an interferogram (a plot of light intensity versus optical path difference) which is then Fourier transformed to yield a spectrum [109]. The thickness of epitaxial layers can be measured by FTIR if interference fringes are present in the reflectance spectrum [110]. The interference fringes are observed in the spectrum if the grown epitaxial layers and the substrate have sufficiently different optical index such as dielectric constant and refractive index. In the case of homoepitaxy the interference fringes are usually present if the doping level between the grown epitaxial layers and the substrate is different. The carrier net concentration of the epitaxial layers and the substrate are usually in the $10^{14}-10^{16} \mathrm{~cm}^{-3}$ and $10^{18}-10^{19} \mathrm{~cm}^{-3}$ ranges respectively. 


\subsection{Capacitance-Voltage (C-V) measurement}

The net carrier concentration of the epitaxial layers can be determined by Capacitance-voltage (C-V) measurement using thermally evaporated metal ( $\mathrm{Ni}$ or Au in case of n-type and a mixture of $\mathrm{Ti}$ and $\mathrm{Al}$ in case of p-type) as the Schottky contact on the epitaxial layers and silver (Ag) as the ohmic contact on the substrate (backside). The use of a mercury-probe where the Schottky and ohmic contact are formed on the epitaxial layer by the mercury is a fast and non-destructive way to estimate the doping level. The capacitance-voltage $(\mathrm{C}-\mathrm{V})$ measurement is based on the fact that the width of a reverse-biased depletion layer (W) of a semiconductor junction device depends on the applied voltage $[111,112]$. The depletion layer of width $\mathrm{W}$ is changed by applying a dc bias voltage $\mathrm{V}$ across the two contacts. The capacitance is estimated by superimposing a small ac test voltage $\mathrm{v}$ on the dc voltage $\mathrm{V}$.

$C=\frac{d Q_{s}}{d V}=-q A N_{d} \frac{d W}{d V}($ Eq. 1)

where $\mathrm{C}$ is the capacitance, $\mathrm{Q}_{\mathrm{s}}$ is the semiconductor charges, $\mathrm{V}$ is the applied voltage, $q$ is electron charge, $A$ is the diode area $N_{d}$ is net doping density and $\mathrm{W}$ is the depletion layer width. The capacitance of a reverse-biased junction is

$$
C=\frac{\mathbf{K}_{\mathrm{s}} \varepsilon_{0} \mathbf{A}}{\mathbf{W}}(\text { Eq. 2) }
$$

when considered as a parallel plate capacitor where $\mathrm{K}_{\mathrm{s}}$ is the semiconductor dielectric constant and $\varepsilon_{0}$ is the vacuum permittivity. The differential of Eq. 2 with respect to $\mathrm{V}$ and substituting $\mathrm{dW} / \mathrm{dV}$ into Eq.1 gives: $\mathbf{N}_{\mathbf{d}}=-\frac{2}{\mathbf{q} \varepsilon_{0} \mathrm{~K}_{\mathbf{s}} \mathrm{A}^{2} \mathbf{d}\left(\frac{1}{\mathbf{c}^{2}}\right) / \mathbf{d V}}$ (Eq. 3).

The doping density is determined from the slope $d\left(1 / C^{2}\right) / d V$ of the a $1 / C^{2}-V$ curve or from the slope $\mathrm{dC} / \mathrm{dV}$ of a C-V curve [111]. 


\subsection{Low Temperature Photoluminescence (LTPL)}

Low temperature photoluminescence (LTPL) is a non-destructive technique to study the quality of grown epitaxial layers. The sample is cooled in a cryostat to low temperature (usually, $\sim 2 \mathrm{~K}$ ) and the luminescence is excited by a laser with a wavelength corresponding to an energy above the band-gap energy $\left(\mathrm{E}_{\mathrm{g}}\right)$ of the sample. The luminescence emitted from the sample is collected with suitable optics and dispersed by a monochromator equipped with a CCD camera. When the laser irradiates the sample, some of the electrons in the valence band will be excited across the band gap to the conduction band, leaving behind a hole in the valence band. Due to their opposite charges, the so-created electron and hole bind together by Coulomb interaction to form an electron-hole pair that is called free exciton (FE). Defects in the crystal (e.g., stacking faults) and impurities (e.g., different donors and acceptors) are capable of capturing the excitons to form bound excitons. Depending on the concentration of different exciton traps in the crystal (defects and impurities), the excitons created by the laser excitation will have different probability to be captured, hence an exciton can recombine either as free, or as a bound exciton. A free exciton can only recombine in a radiative way by emitting the excess energy stored in it as a photon. In an indirect band gap semiconductor such as $\mathrm{SiC}$ the momentum conservation requires that recombination by photon emission must be assisted by phonons, therefore a phonon is either created or absorbed in the recombination process. At low temperature, however, there are no phonons available for absorption; hence a part of the recombination energy equal to the energy of the created phonon ( $\left.E_{\text {phonon }}\right)$ is to be subtracted from the energy of the emitted photon. Thus, the energy of the photon emitted during recombination of a $\mathrm{FE}$ becomes $\hbar \omega=\mathrm{E}_{\mathrm{g}}-\mathrm{E}_{\mathrm{FE}}-\mathrm{E}_{\mathrm{phonon}}$, where $\mathrm{E}_{\mathrm{FE}}$ is the binding energy of the free exciton. In the case of bound-exciton recombination, an additional energy $\mathrm{E}_{\mathrm{BE}}$ equal to the binding energy of the exciton to the imperfection (impurity or defect) has to be subtracted from the 
energy of the emitted photon. Thus, for a bound exciton the photon energy

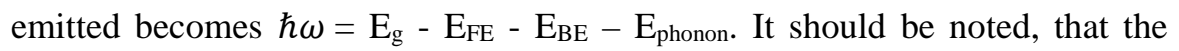
quantity $E_{B E}$ is different for different impurities/defects, allowing identification from the photoluminescence (PL) spectrum of many crystal imperfections. For bound excitons the so-called no-phonon line is allowed, arising from recombination without phonon assistance (this is the dominating emission for strongly-bound excitons). Bound-exciton recombination can be also non-radiative, e.g., in excitons bound to the common $\mathrm{N}$-donor in all polytypes. In this latter case the energy stored in the bound exciton is transferred to the donor electron exciting it in the conduction band and no photon emission occurs (Auger recombination). LTPL measurements are very useful in providing information about different SiC-polytype inclusions (Figure 15), or the presence of stacking faults and other defects in the grown epitaxial layers $[113,114]$. The doping concentration can also be accurately determined [115, 116].
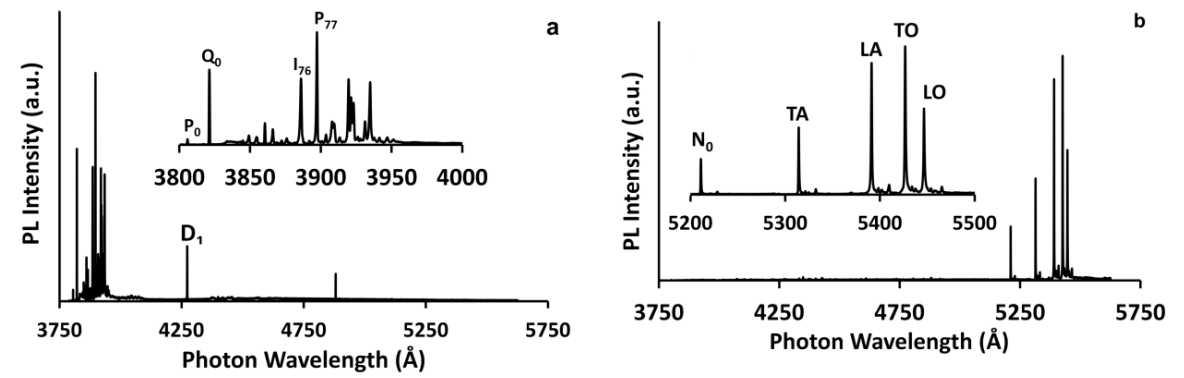

Figure 15: LTPL spectrum of (a) 4H-SiC and (b) 3C-SiC. 


\subsection{KOH Etching}

Potassium hydroxide (KOH) etching is a fast but destructive technique to estimate and compare dislocation densities in the substrate and epitaxial layers. The epitaxial layers and substrates are usually etched in molten potassium hydroxide $(\mathrm{KOH})$ at $500{ }^{\circ} \mathrm{C}$ for 3-5 minutes to selectively etch dislocations on the substrate and epitaxial layers surface. Large hexagonal, small hexagonal and conical etch pits are related to threading screw dislocations (TSD), threading edge dislocations (TED) and basal plane dislocations (BPD) respectively (Figure 16).

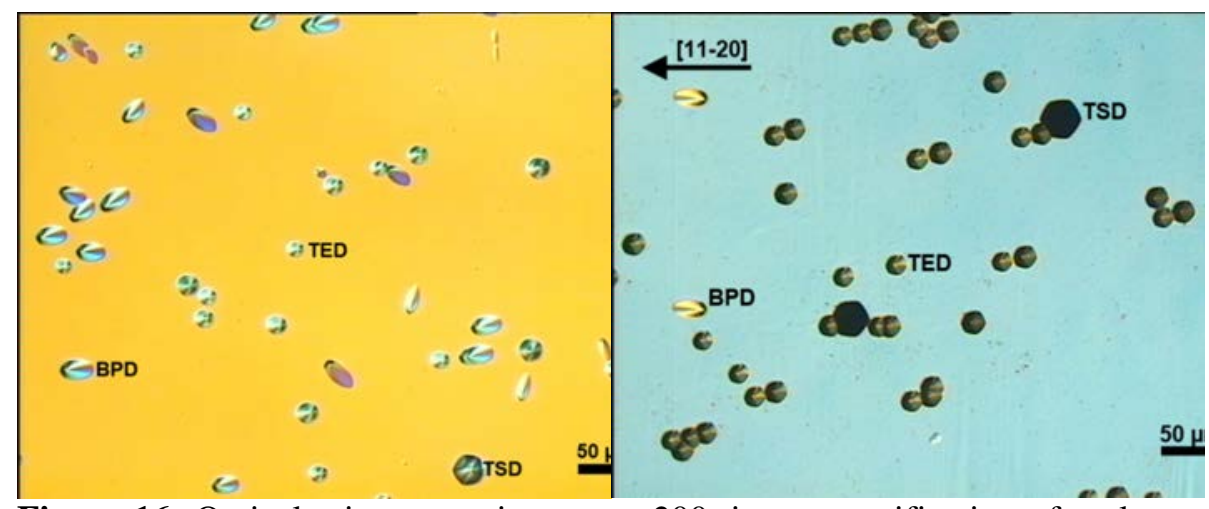

Figure 16: Optical microscope images at 200 times magnification of molten $\mathrm{KOH}$-etched at $500{ }^{\circ} \mathrm{C}$ for 3 minutes (a) $4^{\circ}$ off-cut substrate $4 \mathrm{H}-\mathrm{SiC}$; (b) $100 \mu \mathrm{m}$ thick epitaxial layers. 


\section{Summary of papers}

For all papers the growth experiment were performed in a horizontal hot wall CVD reactor without rotation of the substrate.

\section{Paper 1}

Growth of $4 \mathrm{H}-\mathrm{SiC}$ epitaxial layers on $4^{\circ}$ off-axis substrates with very highquality morphology using methane $\left(\mathrm{CH}_{4}\right)$ as a carbon precursor is demonstrated. We found that a key factor in obtaining high-quality material is tuning the $\mathrm{C} / \mathrm{Si}$ ratio of the process gas mixture to a region where the growth is limited neither by carbon nor by silicon supplies.

\section{Paper 2}

A comparative study of $\mathrm{SiCl}_{4}, \mathrm{SiHCl}_{3}, \mathrm{SiH}_{4}+\mathrm{HCl}, \mathrm{C}_{3} \mathrm{H}_{8}, \mathrm{C}_{2} \mathrm{H}_{4}$ and $\mathrm{CH}_{4}$ in an attempt to find the optimal precursor combination is presented for growth of $4 \mathrm{H}-\mathrm{SiC}$ epitaxial layers on $4^{\circ}$ off-axis substrates with very good morphology. We found that while the chlorinated silanes $\mathrm{SiCl}_{4}$ and especially $\mathrm{SiHCl}_{3}$ give higher growth rate than natural silane and $\mathrm{HCl}, \mathrm{SiH}_{4}+\mathrm{HCl}$ gives better morphology at $\mathrm{C} / \mathrm{Si}$ around 1 and $\mathrm{SiCl}_{4}$ gives the best morphology at low $\mathrm{C} / \mathrm{Si}$. As carbon precursor, $\mathrm{C}_{3} \mathrm{H}_{8}$ or $\mathrm{C}_{2} \mathrm{H}_{4}$ are more or less equal in performance with a slight advantage for $\mathrm{C}_{3} \mathrm{H}_{8}$.

\section{Paper 3}

A direct comparison between chloride-based and bromide-based CVD chemistries for growth of $4 \mathrm{H}-\mathrm{SiC}$ epitaxial layers on $4^{\circ}$ off-axis substrates using $\mathrm{SiH}_{4}$ and $\mathrm{C}_{2} \mathrm{H}_{4}$ as $\mathrm{Si}$ - respectively C-precursors with $\mathrm{HCl}$ or $\mathrm{HBr}$ as growth additives is presented. We found that Br-based chemistry is as robust as $\mathrm{Cl}$-based chemistry and that the growth rate is on average $10 \%$ higher for a bromide-based chemistry compared to a chloride-based chemistry.

\section{Paper 4}


Growth of $4 \mathrm{H}-\mathrm{SiC}$ epitaxial layers on $8^{\circ}$ off-axis substrates using the single molecule precursor methyltrichlorosilane (MTS) with various temperature ramps up conditions is studied in order to evaluate the impact of the temperature ramps up conditions on the carrot defect density. We found that the carrot density is slightly lower in an $\mathrm{HCl}$ ambient in contrast to a $\mathrm{C}_{2} \mathrm{H}_{4}$ ambient. Also the process pressure was found to have a major impact on the carrot defect density.

\section{Paper 5}

Growth of about $200 \mu \mathrm{m}$ thick $4 \mathrm{H}-\mathrm{SiC}$ epitaxial layers on $8^{\circ}$ off-axis substrates with very good morphology at growth rates exceeding $100 \mu \mathrm{m} / \mathrm{h}$ using $\mathrm{SiCl}_{4}+\mathrm{C}_{2} \mathrm{H}_{4}$ and $\mathrm{SiH}_{4}+\mathrm{HCl}+\mathrm{C}_{2} \mathrm{H}_{4}$ precursor approaches is reported. We found that a $\mathrm{C} / \mathrm{Si}$ ratio $<1$ and an optimized in-situ etch are shown to be the key parameters to achieve $200 \mu \mathrm{m}$ thick, low doped epitaxial layers with excellent morphology. For the $\mathrm{SiCl}_{4}$-based process a decreased $\mathrm{C} / \mathrm{Si}$ was found to be necessary for the growth of $190 \mu \mathrm{m}$ thick epitaxial layers with excellent morphology. For the $\mathrm{SiH}_{4}$-based process, the use of a lower $\mathrm{C} / \mathrm{Si}$ ratio also improved the morphology and it was possible to grow high $10^{14} \mathrm{~cm}^{-3}$ doped $230 \mu \mathrm{m}$ thick and low $10^{14} \mathrm{~cm}^{-3}$ doped $180 \mu \mathrm{m}$ thick epitaxial layers with good morphology.

\section{Paper 6}

The effect of the process parameters on the dislocation density was investigated by performing $\mathrm{KOH}$ etching on $100 \mu \mathrm{m}$ thick epitaxial layers grown on $4^{\circ}$ off axis $4 \mathrm{H}-\mathrm{SiC}$ substrates at various growth conditions using $\mathrm{SiH}_{4}+\mathrm{C}_{2} \mathrm{H}_{4}+\mathrm{HCl}$ chemistry to achieve growth rates exceeding $100 \mu \mathrm{m} / \mathrm{h}$. We found that the growth temperature and the growth rate have no significant influence on the dislocation density in the grown epitaxial layers. The in situ etching prior to growth was found to have a great effect on reducing the BPD 
density. On the epitaxial layers having very high step height no BPDs were observed.

\section{Paper 7}

The effect of varying parameters such as growth temperature, $\mathrm{C} / \mathrm{Si}$ ratio, $\mathrm{Cl} / \mathrm{Si}$ ratio, $\mathrm{Si} / \mathrm{H}_{2}$ ratio and in situ pre-growth surface etching time are studied in order to reduce the formation of step bunching and structural defects. The main focus was on the formation of triangular defects on approximately $100 \mu \mathrm{m}$ thick $4 \mathrm{H}-\mathrm{SiC}$ epitaxial layers on $4^{\circ}$ off-axis substrates with otherwise very good morphology at growth rates up to $115 \mu \mathrm{m} / \mathrm{h}$. We found that $100 \mu \mathrm{m}$ step-bunch free epitaxial layer with a minimum triangular defect density and excellent morphology could be grown by applying a slightly lower growth temperature of $1575^{\circ} \mathrm{C}$, a C/Si ratio of 0.8 and a $\mathrm{Cl} / \mathrm{Si}$ ratio of 5 . 


\section{My contribution to the papers}

\section{Paper 1}

I have planed the experiments and performed all growth runs and most of the characterizations. I have written the paper with the help of the co-authors.

\section{Paper 2}

I have planed the experiments and performed all growth runs and most of the characterizations. I have written the paper with the help of the co-authors.

\section{Paper 3}

I have planed the experiments and performed all growth runs and most of the characterizations. I have written the paper with the help of the co-authors.

\section{Paper 4}

I have planed the experiments and performed all growth runs and most of the characterizations. I have written the paper.

\section{Paper 5}

I have planed the experiments and performed growth runs and characterizations with the co-authors. I have written the paper.

\section{Paper 6}

I have planed the experiments and performed all growth runs and most of the characterizations. I have written the paper.

\section{Paper 7}

I have planed the experiments and performed all growth runs and most of the characterizations. I have written the paper. 


\section{References}

[1] A.R.Verma, P. Krishna, Polymorphism and Polytypism in Crystals, Wiley, New York, 1966.

[2] H. Matsunami, T. Kimoto, Materials Science and Engineering, R20 (1997) 125.

[3] W. J. Choyke, D. R. Hamilton, L. Patrick, Physical Review 133 (1964) A1163.

[4] A. Qteish, V. Heine, R. J. Needs, Physical Review B 45 (1992) 169.

[5] W. von Muench, I. Pfaffeneder, Journal of Applied Physics, 48 (1977) 4831.

[6] D.W. Feldman, J.H. Parker Jr., W.J. Choyke, L. Patrick, Physical Review, 173 (1968) 787.

[7] G.A. Slack, Journal of Applied Physics, 35 (1964) 3460.

[8] W. von Muench, E. Pettenpaul, Journal of Applied Physics, 48 (1977) 4823.

[9] V.E. Chelnokov, A.L. Syrkin, Materials Science and Engineering B, 46 (1997) 248.

[10] A. A. Lebedev, V. E. Chelnokov, Semiconductors, 33 (1999) 999.

[11] F. Roccaforte, F. Giannazzo, F. Iucolano, J. Eriksson, M.H. Weng, V. Raineri, Applied Surface Science 256 (2010) 5727.

[12] H. Morkoç, S. Strite, G. B. Gao, M. E. Lin, B. Sverdlov, M. Burns, Journal of Applied Physics, 76 (1994) 1363.

[13] A. Elasser, T. P. Chow, Proceedings of the IEEE, 90 (2002) 969.

[14] D. Han, J. Noppakunkajorn, B. Sarlioglu, 2013 IEEE Transportation Electrification Conference and Expo: Components, Systems, and Power Electronics - From Technology to Business and Public Policy, ITEC 2013 ISBN: 9781-479901463.

[15] R. Singh, J. A. Cooper, M. R. Melloch, T. P. Chow, J. W. Palmour, IEEE Transactions on electron devices, 49 (2002) 665. 
[16] J. A. Cooper, A. Agarwal, Proceeding of the IEEE, 90 (2002) 956.

[17] A. G. Acheson, Eugl. Patent 17911 (1892).

[18] W. F. Knippenberg, Philips Research Reports 18 (1963) 161.

[19] J. A. Lely, Berichte der Deutschen Keramischen Gesellschaft 32 (1955) 229.

[20] Yu. M. Tairov, Materials Science and Engineering B29 (1995) 83.

[21] Yu. M. Tairov, V. F. Tsvetkov, Journal of Crystals Growth 43 (1978) 209.

[22] D. L. Barret, R. G. Seidensticker, W. Gaida, R. H. Hopkins, Journal of Crystals Growth 109 (1991) 17.

[23] D.L. Barrett, J.P. McHugh, H.M. Hobgood, R.H. Hopkins, P.G. McMullin, R.C. Clarke, Journal of Crystals Growth 128 (1993) 358.

[24] www. Cree.com

[25] www. SiCrystal.com

[26] www. Norstel.com

[27] O. Kordina, C. Hallin, A. Ellison, A. S. Bakin, I. G. Ivanov, A. Henry, R. Yakimova, M. Touminen, A. Vehanen, E. Janzén, Applied Physics Letters 69 (1996) 1456.

[28] A. Ellison, B. Magnusson, C. Hemmingsson, W. Magnusson, T. Iakimov, L. Storasta, A. Henry, N. Henelius, E. Janzén, Materials Research Society Symposium Proceedings 640 (2001) H1.2.1.

[29] A. Ellison, J. Zhang, J. Peterson, A. Henry, Q. Wahab, J.P. Bergman, Y.N. Makarov, A. Vorob'ev, A. Vehanen, E. Janzén , Materials Science and Engineering B61-62 (1999) 113.

[30] H. J. Chung, A. Y. Polyakov, S. W. Huh, S. Nigam, M. Skowronski, M. A. Fanton, B. E. Weiland, D. W.Snyder, Journal of Applied Physics 97 (2005) 084913.

[31] M. A. Fanton, B. E. Weiland, D. W. Snyder, J. M. Redwing, Journal of Applied Physics 101 (2007) 014903. 
[32] S. Leone, F. C. Beyer, A. Henry, C. Hemmingsson, O. Kordina, E. Janzén, Crystal Growth and Design 10 (2010) 3743.

[33] A. C. Jonse, P. O’Brien, CVD of Compound Semiconductors, VCH, Weinheim, 1997.

[34] F. Wischmeyer, E. niemann, H.L. Hartnagel, Journals of Electronics Materials, 28 (1999) 175.

[35] R. Rupp, A. Wiedenhofer, P.Friedrichs, D. Peters, R. Schörner, D. Stephani, Materials Science Forum 264-268 (1998) 89.

[36] J. Zhanga, A. Ellison, Ö. Danielsson, M.K. Linnarsson, A. Henry, E. Janzén, Journal of Crystal Growth 241 (2002) 421.

[37] O. kordina, A. Henry, E. Janzén, C. H. Carter, Materials Science Forum 264-268 (1998) 97.

[38] A. Henry, J. Hassan, J. P. Bergman, C. Hallin, E. Janzén, Chemical Vapor Deposition 12 (2006) 475.

[39] J.A.Cooper,A.Agarwal, ProceedingsoftheIEEE90 (2002) 956.

[40] R.L. Myers, Y. Shishkin, O. Kordina, S.E. Saddow, Journal of Crystals Growth 285 (2005) 486.

[41] J.Zhang, J. Mazzola, C. Hoff, Y. koshka, J. Casady, Materials Science Forum 483-485 (2005) 77.

[42] H. Tsuchida, I. Kamata, T. Jikimoto, K. Izumi, Journal of Crystals Growth 237-239 (2002) 1206.

[43] A. Ellison, J. Zhang, A. Henry, E. Janzén, Journal of Crystals Growth 236 (2002) 225.

[44] Y.Ishida,T.Takahashi,H.Okumura,K.Arai,S.Yoshida, Materials Science Forum 600-603 (2009)119.

[45] M. Ito, L.Storasta, H.Tsuchida, Applied Physics Express1(2008) 015001.

[46] H. Pedersen, S. Leone, O. Kordina, A. Henry, S. Nishizawa, Y. Koshka, E. Janzén , Chemical Reviews. 112 (2012) 2434. 
[47] D. Crippa, G.L. Valente, A. Ruggiero, L. Neri, R. Reitano, L. Calcagno, G. Foti, M.Mauceri, S. Leone,G. Pistone, G. Abbondanza, G. Abbagnale, A. Veneroni, F. Omarini, L. Zamolo, M. Masi, F.Roccaforte, F. Giannazzo,S. Di Franco, F. La Via, Materials Science Forum 483-485 (2005)67.

[48] R. Myers, O. Kordina, Z. Shishkin, S. Rao, R. Everly, S. E. Saddow, Materials Science Forum 483-485 (2005) 73.

[49] F. La Via, G. Galvagno, G. Foti, M. Mauceri, S. Leone, G. Pistone,G. Abbondanza, A. Veneroni, M. Masi, G. L. Valente, D. Crippa,Chemical Vapor Deposition 12 (2006) 509.

[50] H. Pedersen, S. Leone, A. Henry, A. Lundskog, E. Janzén, physica status solidi (RRL) 2 (2008) 278.

[51]

F.LaVia,G.Izzo,M.Mauceri,G.Pistone,G.Condorelli,L.Perdicaro,G.Abbondanz a,

L. Calcagno,G.Foti,D.Crippa, Journal of Crystals Growth 311(2008)107.

[52] S. Leone, M. Mauceri, G. Pistone, G. Abbondanza, F. Portuese, G.Abagnale, G.L. Valente, D. Crippa, M. Barbera, R. Reitano, G. Foti, F. La Via, Materials Science Forum 527-529 (2006) 179.

[53] M.F. MacMillan, M. J. Loboda, G. Chung, E. Carlson, J. Wan, Materials Science Forum 527-529 (2006) 175.

[54] G. Dhanaraj, M. Dudleya, Y. Chen, B. Ragothamachar, B. Wu, H. Zhang, Journal of Crystals Growth 287 (2006) 344.

[55] G. Dhanaraj, Y. Chen, M. Dudley, H. Zhang, Materials Science Forum 527-529 (2006) 67.

[56] M. Yazdanfar, P.Stenberg, I.D.Booker, I.G.Ivanov, O.Kordina, H.Pedersen, E.Janzén, Journals of Crystals Growth 380 (2013) 55.

[57] H. Pedersen, S. Leone, A. Henry, F. C. Beyer, V. Darakchieva, E.Janzén, Journals of Crystals Growth 307 (2007) 334.

[58] H. Pedersen, S. Leone, A. Henry, V. Darakchieva, P. Carlsson, A. Gällström, E. Janzén, Physica Status Solidi (RRL) 2 (2008) 188.

[59] R. W. Bartlett, R. A. Mueller, Materials Research Bulletin 4 (1969) 341. 
[60] V. V. Zelenin, V. G. Solov’ev, S. M. Starobinets, S. G. Konnikov, V. E. Chelnokov, Semiconductors 29 (6) (1995) 581.

[61] G. Aylward, T. Findlay, SI Chemical Data, fourth ed., Wiley, Milton, Australia, (2008)125.

[62] A. Veneroni, M. Masi, Chemical Vapor Deposition 12 (2006) 562.

[63] A. Veneroni, F. Omarini, M. masi, Crystal Research and Technology 40 (2005) 967.

[64] Y. Koshka, H. D. Lin, G. Melnychuka, C. Wood, Materials Science Forum 527-529 (2006)167.

[65] Y. Koshka, H. D. Lin, G. Melnychuka, C. Wood, Journals of Crystals Growth 294 (2006) 260.

[66] T. Rana, M. V. S. Chandrashekar, T. S. Sudarshan, Physica Status Solidi A 209 (2012) 2455.

[67] Th. Kunstmann, H. Angerer, J. Knecht, S. Veprek, Chemistry of Materials 7 (1995) 1675.

[68] Th. Kunstmann, S. Veprek, Applied Physics Letters 67 (1995) 3126.

[69] M.Yazdanfar , E. Kalered, Ö. Danielsson, O. Kordina, D. Nilsson, I. G. Ivanov, L. Ojamäe, E. Janzén, H. Pedersen

[70] N. Kuroda, K. Shibahara, W. S. Yoo, S. Nishino, and H. Matsunami, "Step-controlled VPE growth of SiC single crystals at low temperatures," in 19th Conference on Solid State Devices and Materials (Tokyo, 1987), p. 227.

[71] W. Chen and M. A. Capano, Journal of Applied Physics 98 (2005) 114907.

[72] H. Tsuchida, M. Ito, I. Kamata, and M. Nagano, Materials Science Forum 615-617 (2009) 67.

[73] J. P. Bergman, H. Jakobsson, L. Storasta, F. H. C. Carlsson, B.

Magnusson, S. Sridhara, G. Pozina, H. Lendenmann, and E. Janzén, Materials Science Forum 389-393 (2002) 9.

[74] M. K. Das, J. J. Sumakeris, B. A. Hull, J. Richmond, S. Krishnaswami, A. R. Powell, Materials Science Forum 483-485 (2005) 965. 
[75] Z. Zhang and T. S. Sudarshan, Applied Physics Letters 87 (2005)151913.

[76] T. Kimoto, A. Itoh, H. Matsunami, and T. Okano, Journal of Applied Physics 81 (1997) 3494.

[77] K. Wada, T. Kimoto, K. Nishikawa, and H. Matsunami, Journal of Crystals Growth 291 (2006) 370.

[78] J. E. Chung, J. Chen, P. K. Ko, C. Hu, and M. Levi, IEEE Transactions on Electron Devices 38 (1991) 627.

[79] S. Leone, H. Pedersen, A. Henry, O. Kordina, and E. Janzén, Journal of Crystals Growth 311 (2009) 3265.

[80] L. Dong, G. Sun, J. Yu, L. Zheng, X. Liu, F. Zhang, G. Yan, X. Li, and Z. Wang, Applied Surface Science 270 (2013) 301.

[81] T. Kimoto, A. Itoh, H. Matsunami, Applied Physics Letters 67 (1995) 2385.

[82] J. A. Powell, J. B. Petit, J. H. Edgar, I. G. Jenkins, L. G. Matus, J. W. Yang, P. Pirouz, W. J. Choyke, L. Clemen, and M. Yoganathan, Applied Physics Letters 59 (1991) 333.

[83] C. Hallin, F. Owman, P. Mårtensson, A. Ellison, A. Konstantinov, O. Kordina, E. Janzén, Journal of Crystals Growth 181 (1997) 241.

[84] G. Aylward and T. Findlay, SI Chemical Data, 6th ed. (John Wiley and Sons Australia, Ltd, Milton, Brisbane, 2008).

[85] A. A. Burk and L. B. Rowland, Applied Physics Letters 68 (1996) 382.

[86] M. Yazdanfar, S. Leone, H. Pedersen, O. Kordina, A. Henry, E. Janzén, Materials Science Forum 717-720 (2012) 109.

[87] S. Leone, F. C. Beyer, H. Pedersen, O. Kordina, A. Henry, E. Janzén, Crystals Growth and Design 10 (2010) 5334.

[88] M. Yazdanfar, I. G. Ivanov, H. Pedersen, O. Kordina, E. Janzén, Journal of Applied Physics 113 (2013) 223502.

[89] S. Leone, F. C. Beyer, H. Pedersen, S. Andersson, O. Kordina, A. Henry, E. Janzén, Thin Solid Film 519 (2011) 3074. 
[90] U. Forsberg, Ö. Danielsson, A. Henry, M.K. Linnarsson, E. Janzén, Journal of Crystals Growth 236 (2002) 101.

[91] R. Wang, I. B. Bhat, T. P. Chow, Journal of Applied Physics 92 (2002) 7587.

[92] K. Kojima, T. suzuki, S. Kuroda, J. nishio, K. arai, Japanese Journal of Applied Physics 42 (2003) L637.

[93] H. Pedersen, F.C.Beyer, J.Hassan, A.Henry, E. Janzén, Journal of Crystals Growth 311 (2009) 1321.

[94] S.Leone, A. Henry, S. Andersson, O. Kordina, E. Janzén, Journal of the Electrochemical Society, 157 (10) (2010) H969.

[95] G. Wagner, K. Irmscher, Materials Science Forum 353-356 (2001) 95.

[96] T. Kimoto, H. Nishino, W. S. Yoo, and H. Matsunami, Journal of Applied Physics 73 (1993) 726.

[97] A. Fissel, Journal of Crystals Growth 212 (2000) 438.

[98] Y. Ishida, T. Takahashi, H. Okumura, K. Arai, and S. Yoshida, Materials Science Forum 600-603 (2009) 473.

[99] D. J. Larkin, P. G. Neudeck, J. A. Powell, and L. G. Matus, Applied Physics Letters 65 (1994) 1659.

[100] T. Kimoto, A. Itoh, and H. Matsunami, Applied Physics Letters 67 (1995) 2385.

[101] U. Forsberg, Ö. Danielsson, A. Henry, M. K. Linnarsson, E. Janzén, Journal of Crystals Growth 236 (2002) 101.

[102] H. Pedersen, F. C. Beyer, J. Hassan, A. Henry, E. Janzén, Journal of Crystals Growth 311 (2009) 1321.

[103] H. Pedersen, S. Leone, A. Henry, A. Lundskog, E. Janzén, Physica Status Solidi (RRL) 2 (2008) 278.

[104] C. Hallin, I. G. Ivanov, T. Egilsson, A. Henry, O. Kordina, E. Janzén, Journal of Crystals Growth 183 (1998) 163. 
[105] M. Yazdanfar, H. Pedersen, P. Sukkaew, I. G. Ivanov, Ö. Danielsson, O. Kordina, E. Janzén, Journal of Crystals Growth 390 (2014) 24.

[106] M.Yazdanfar , Ö. Danielsson, O. Kordina, E. Janzén, H. Pedersen ECS Journal of Solid State Science and Technology, 3 (10) (2014) P320.

[107] Veeco SPM Training Notebook.

[108] M. F. MacMillan, A. Henry, E. Janzén, Journal of Electronic Materials 27 (1998) 300.

[109] Brian C. Smith, Fundamentals of Fourier Transform Infrared Spectroscopy, Taylor and Francis Group, LLC 2011.

[110] M. F. MacMillan, P. O. Narfgren, A. Henry, E. Janzén, Materials Science Forum 264-268 (1998) 645.

[111] Dieter K. Schroder, Semiconductor Material and Device Characterization, John Wiley and Sons 2006.

[112] P. Blood and J. W. Orton, The Electrical Characterization of Semiconductors: Majority Carriers and Electron States, Academic Press 1992.

[113] R. P. Devaty, W. J. Choyke, Physica Status Solidi A 162 (1997)5.

[114] A. Henry, C. Hallin, I. G. Ivanov, J. P. Bergman, O. Kordina, U. Lindefelt, E. Janzén, Physical Review B 53 (13) (1996) 13503.

[115] I. G. Ivanov, C. Hallin, A. Henry, O. Kordina, E. Janzén, Journal of Applied Physics 80 (1996) 3504.

[116] I. G. Ivanov, U. Lindefelt, A. Henry, O. Kordina, C. Hallin, M. Aroyo, T. Egilsson, E. Janzén, Physical Review B 58 (20) (1996) 13634. 
II. Publication 


\section{Publications}

The articles associated with this thesis have been removed for copyright reasons. For more details about these see:

http://urn.kb.se/resolve?urn=urn:nbn:se:liu:diva-111076 